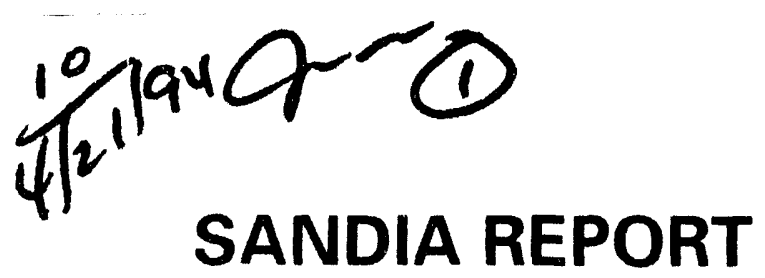

SAND94-8211 • UC-40 44

Unlimited Release 234

Printed March 1994

\title{
Corrosion of Stainless and Carbon Steels in Molten Mixtures of Industrial Nitrates
}

S. H. Goods, R. W. Braushaw, M. R. Prairie, J. M. Chavez

\section{Prepared by}

Sandia National Laboratories

Albuquerque, New Mexico 87185 and Livermore, California 94551-0969

for the United States Department of Energy

under Contract DE-AC04-94AL85000 


\begin{abstract}
Issued by Sandla National Laboratories, operated for the United States Department of Energy by Sandia Corporation.

NOTICE: This report was prepared as an account of work sponsored by an agency of the United States Government. Neither the United States Government nor any agency thereof, nor any of their employees, nor any of the contractors, subcontractors, or their employees, makes any warranty, express or implled, or assumes any legal liability or responsibility for the accuracy, completeness, or usefulness of any information, apparatus, product, or process disclosed, or represents that its use would not infringe privately owned rights. Reference herein to any speciflc commercial product, process, or service by trade name, trademark, manufacturer, or otherwise, does not necessarily constitute or imply its endorsement, recommendation, or favoring by the United States Government, any agency thereof or any of their contractors or subconractors. The views and opinions expressed herein do not necessarlly state or reflect those of the Unlted States Government, any agency thereof or any of their contractors or subcontractors.
\end{abstract}

This report has been reproduced from the best available copy.

Available to DOE and DOE contractors from:

Office of Scientific and Technical Information

P.O. Box 62

Oak Ridge TN 37831

Prices available from (615) 576-8401, FTS 62.6-8401.

Available to the public from:

National Technical Information Service

U.S. Department of Commerce

5285 Port Royal Rd.

Springfield, VA 22161

NTIS price codes

Printed copy: A15

Microfiche copy: A01 
SAND 94-8211

Unlimited Release

Printed March 1994

$\mathrm{UC}-404$

\title{
CORROSION OF STAINLESS AND CARBON STEELS IN MOLTEN MIXTURES OF INDUSTRI_LL NITRATES
}

\author{
S. H. Goods \\ Materials Performance Department \\ R. W. Bradshaw \\ Materials Synthesis Department \\ Sandia National Laboratories/California \\ M. R. Prairie and J. M. Chavez \\ Solar Thermal Technology Department \\ Sandia National Laboratories/New Mexico
}

\begin{abstract}
The isothermal corrosion behavior of two stainless steels and carbon steel in mixtures of $\mathrm{NaNO}_{3}$ and $\mathrm{KNO}_{3}$ has been evaluated to determine if the impurities found in commodity grades of alkali nitrates aggravate corrosivity as applicable to an advanced solar thermal energy system. Corrosion tests were conducted for approximately 7000 hours with Types 304 and 316 stainless steels at $570^{\circ} \mathrm{C}$ and $\mathrm{A} 36$ carbon steel at $316^{\circ} \mathrm{C}$ in seven mixtures of $\mathrm{NaNO}_{3}$ and $\mathrm{KNO}_{3}$ containing variations in impurity concentrations. Corrosion tests were also conducted in a ternary mixture of $\mathrm{NaNO}_{3}, \mathrm{KNO}_{3}$, and $\mathrm{Ca}\left(\mathrm{NO}_{3}\right)_{2}$. Corrosion rates were determined by descaled weight losses while oxidation products were examined by scanning electron microscopy, electron microprobe analysis, and X-ray diffraction. The nitrate mixtures were periodically analyzed for changes in impurity concentrations and for soluble corrosion products.
\end{abstract}

Results of these tests indicated that the short-term corrosion rates of the stainless steel specimens in many of the mixtures could be described in terms of parabolic kinetics. However, no single rate law could be assigned to the corrosion kinetics resulting from exposure in all of the mixtures. For engineering applications, corrosion rates over the entire exposure period are best described as linear with respect to time. In the binary nitrate mixtures, the annualized rates of metal loss were found to be between 6 and $15 \mu \mathrm{m} / \mathrm{yr}$ for the stainless steel specimens at $570^{\circ} \mathrm{C}$ depending on the particular mixture. Metal loss for the carbon steel specimens immersed in these same mixtures at $316^{\circ} \mathrm{C}$ extrapolated to approximately 1 to $4 \mu \mathrm{m} / \mathrm{yr}$. Scanning electron microscopy and X-ray diffraction revealed that the complex, multiphase surface oxides formed on the stainless steel coupons were comprised primarily of iron-chromium spinel, iron oxides, and sodium ferrite. Magnetite was the principal corrosion product formed on the carbon steel specimens.

Overall, for the typical range of impurities in commercially available nitrate salts, corrosion rates for solar thermal energy applications remained acceptable for all of the materials examined.

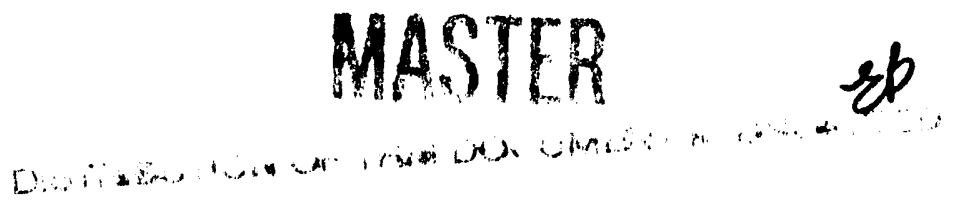




\section{ACKNOWLEDGMENTS}

The authors wish to acknowledge the contribution of the following individuals:

S. R. Dunkin and L. R. Evans (SNL/NM), W. Y. Yoshimoto, A. D. Gardea, C. Rood, and D. R. Boehme (SNL/CA). This work was supported by the U.S. Department of Energy under contract DE-AC04-94AL85000. 


\section{CONTENTS}

Page

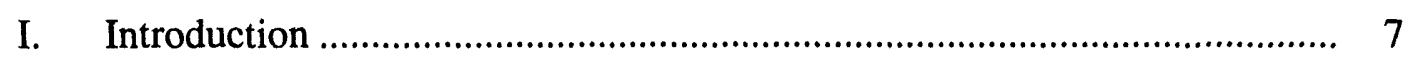

II. Experimental............................................................................. 8

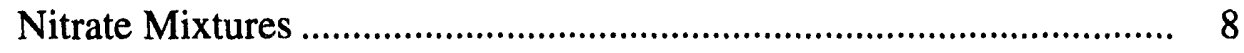

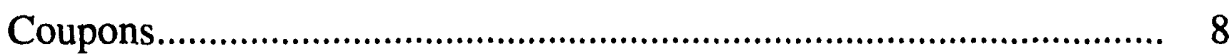

III. Results and Discussion .................................................................... 11

Stainless Steels ............................................................................ 11

Descaled Weight Loss ............................................................ 11

Oxide Adherence .................................................................... 17

Oxide Structure and Composition .............................................. 18

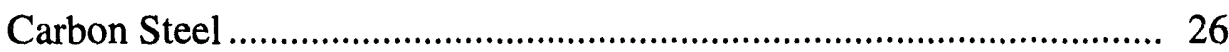

Descaled Weight Loss .......................................................... 26

Oxide Adherence …………………..................................... 29

Salt Composition ........................................................................ 29

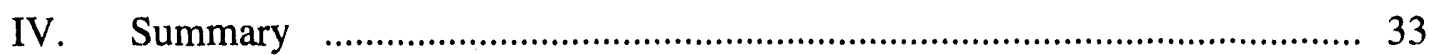

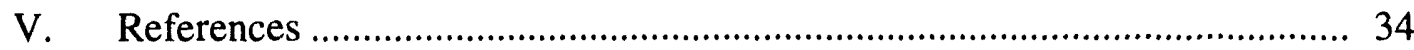

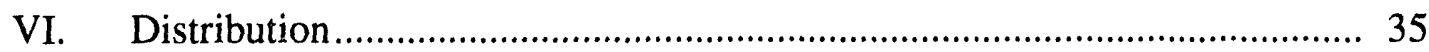




\section{FIGURES}

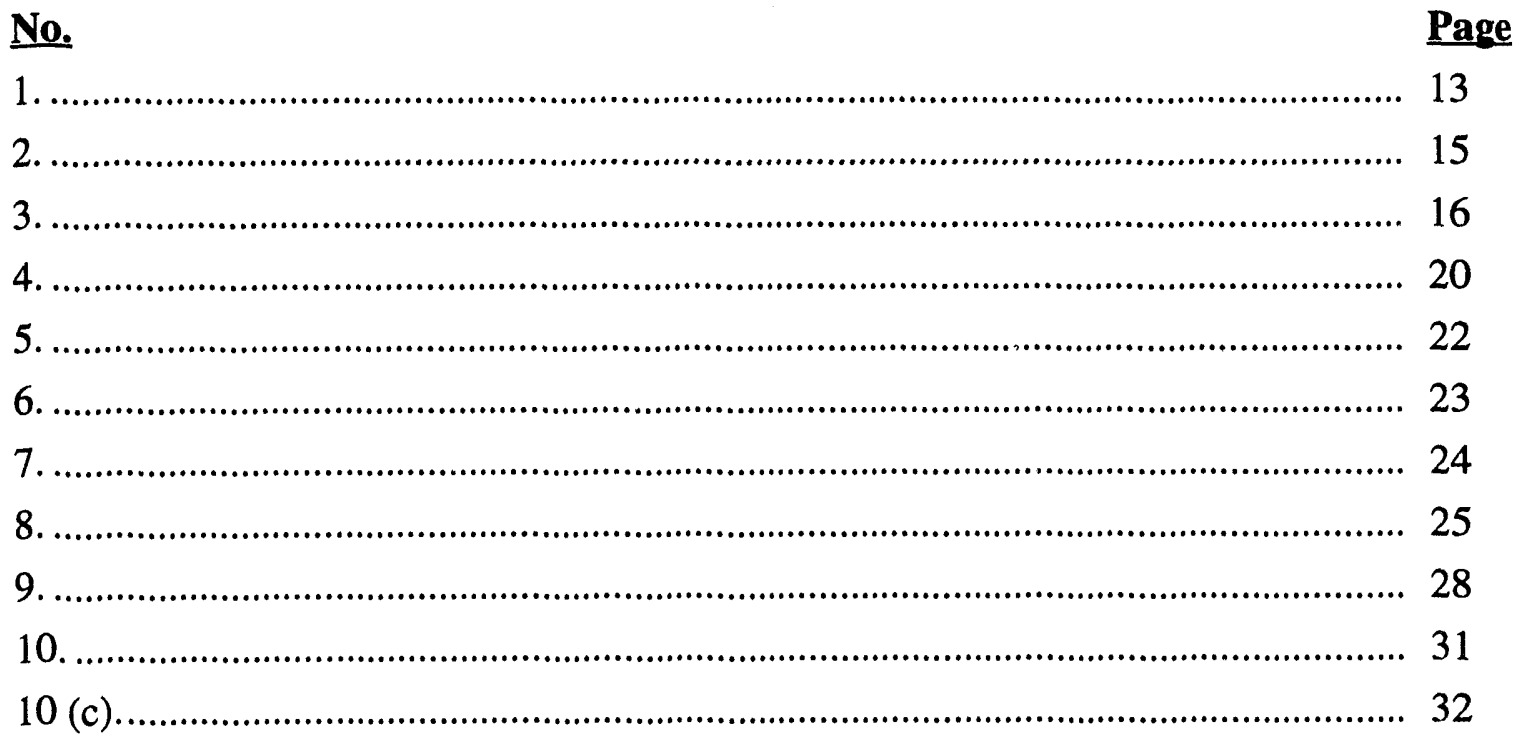

\section{TABLES}

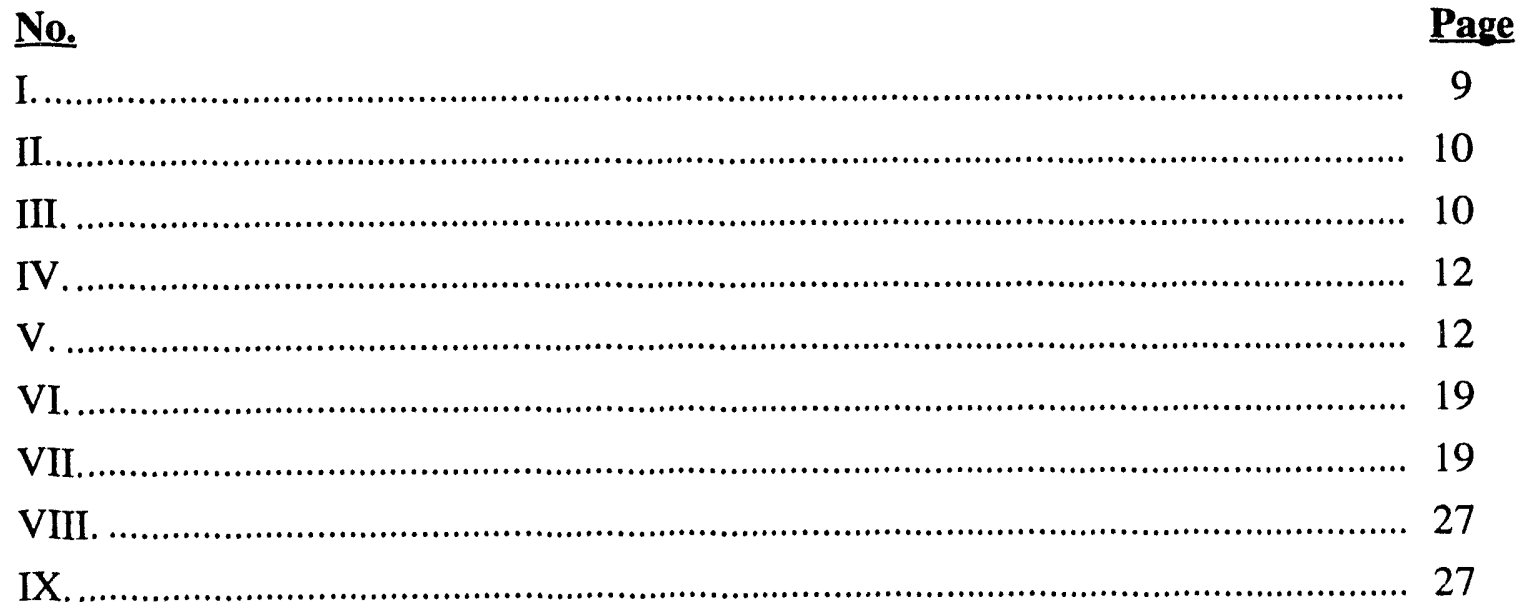




\section{CORROSION OF STAINLESS AND CARBON STEELS IN MOLTEN MIXTURES OF INDUSTRIAL NITRATES}

\section{INTRODUCTION}

This work examines the isothermal corrosion behavior of primary containment materials that will be used in Solar Two, a 10 megawatt (peak electric) solar central receiver power demonstration plant [1]. This technology demonstration has been undertaken as a joint project between a consortium of electric power utilities and the U.S. Department of Energy. In the proposed system, the receiver structure consists of a number of tubing panels through which will circulate a heat transfer fluid that is heated by sunlight focused by an array of computer-controlled mirrors (heliostats). The heat transfer fluid chosen for this demonstration is a molten salt consisting of $60 \mathrm{wt} . \% \mathrm{NaNO}_{3}$ and $40 \mathrm{wt} . \% \mathrm{KNO}_{3}$, which has a melting point of $238^{\circ} \mathrm{C}$ and an intended working range of $290^{\circ} \mathrm{C}$ to $570^{\circ} \mathrm{C}$. These proportions of the individual nitrates were chosen because the resulting mixture optimizes a number of important properties, including heat capacity, thermal conductivity, corrosivity, ease of handling and storage, and cost.

It is expected that a carbon steel will be used to construct the low temperature portions of the system and a higher performance material, such as a stainless steel, will be used in high temperature portions (e.g., the receiver). We have chosen to examine A36 as the carbon steel and 304SS and 316SS as they represent likely and low cost candidates for each of these temperature regimes. The 300 series stainless steels are good choices for this study as previous work has shown that they exhibit good corrosion resistance and no degradation in mechanical properties after relatively long-term exposure to molten nitrates at the temperatures of interest [2-5].

Large quantities of molten salt are needed to optimize the thermal energy storage capacity of this system. It is expected that the total inventory of salt in the Solar Two facility will be about 1.5 million kilograms in order to provide thermal energy storage equivalent to four hours of peak electric power generation. Because of the very large salt inventory, it is important to select the most economical grades of these nitrates salts that satisfy the engineering requirements. A cost savings of nearly $\$ 1 \mathrm{M}$ dollars can be realized by choosing low-cost nitrates. Since these lower cost grades of nitrate can have higher impurity concentrations, it is necessary to assess their impact on containment material compatibility. The impurities typically present in some grades of nitrates, such as $\mathrm{NaCl}$, $\mathrm{KClO}_{4}, \mathrm{Na}_{2} \mathrm{SO}_{4}$, alkalinity, etc., must not aggravate corrosion of the containment alloys. For example, dissolved chloride may be a concern since it is often found to accelerate corrosion in high temperature oxidizing environments [6].

While the previous studies mentioned above have established that high purity nitrates constitute a relatively benign corrosion environment, there is little specific information regarding the effects of impurities on corrosion resistance. A recent paper concerning the effect of sulfate ion on corrosion of mild steel in nitrate melts reported that corrosion rates increased $20 \%$ when $7.5 \mathrm{wt} . \% \mathrm{Na}_{2} \mathrm{SO}_{4}$ was added [7]. For chloride impurities, a few papers in the technical literature describe the results of short-term nitrate exposures, although at temperatures much higher than our application. The results generally indicate that chloride ion concentrations above $0.3 \mathrm{wt} . \%$ measurably increase corrosion rates of iron and carbon steels compared to chloride-free melts [8-10]. Because of these findings, one specific goal of the current work was to address the question of increasing chloride concentration on corrosivity. 


\section{EXPERIMENTAL}

\section{Nitrate Mixtures}

Seven binary mixtures and one ternary nitrate mixture were examined in this study and are listed in Table I. All of the binary mixtures had the same nominal composition of $60 \%$ (wt.) $\mathrm{NaNO}_{3}$ and $40 \% \mathrm{KNO}_{3}$. The first three mixtures were derived from a single source of relatively high purity salt. Mixtures \#2 and \#3 were comprised of the same 60/40 mixture as \#1 but with deliberate additions of chloride ion (as $\mathrm{NaCl}$ ). The maximum chloride addition was $1.3 \mathrm{wt} . \%$, which is $30 \%$ more than the highest expected level in commercial grades of salt. The intent of using these three mixtures was to systematically examine the effect of increasing chloride concentration on the corrosion behavior in the absence of significant amounts of other impurities. Mixtures \#4 - \#7 were melted from other commercially available nitrates containing somewhat higher impurity concentrations. The sources and nominal composition of these mixtures are also shown in Table I. In addition to these binary salt compositions, we have also examined the corrosivity of a ternary mixture chosen because it has an appreciably lower melting point $\left(160^{\circ} \mathrm{C}\right)$. The initial concentrations of some of the principal impurities in the nitrate mixtures used for the experiments are shown in Table II. These values were determined using standard chemical analysis techniques. Since dissolved chloride may not be the only specie influencing the corrosion characteristics of the alloys studied, other potentially important impurities present in the nitrate mixtures, including perchlorate, sulfate, and carbonate are listed. Finally, the initial concentration of nitrite $\left(\mathrm{NO}_{2}^{-}\right)$, an equilibrium constituent of the nitrate system, is also shown in Table II.

\section{Coupons}

The nominal compositions of the test alloys, A36 carbon steel, 304SS and 316SS, are shown in Table III. Rectangular coupons measuring approximately $20 \mathrm{~mm} \times 50 \mathrm{~mm} \times 2 \mathrm{~mm}$ in thickness were cut from sheet stock, cleaned, alcohol rinsed, and weighed prior to immersion in the melts. Because of the large number of coupons, the samples were used with the as-received surface finish rather than being prepared identically. The 304SS starting stock appeared to have a surface finish similar to that produced by wire brushing. The A36 and 316SS starting stock appeared to have a smoother finish typical to that produced by a rolling operation. Several additional coupons of $316 S S$ were ground with 180 grit carborundum paper and placed in crucibles \#1, \#3, and \#6 to compare their corrosion behavior with the as-received coupons. Two weldments of each stainless steel were also prepared for testing in each salt mixture by making single-pass welds using $308 \mathrm{~L}$ weld wire.

The A36 coupons were fully immersed in crucibles constructed from carbon steel. All of the stainless steel coupons were immersed in crucibles constructed of 304SS. Each crucible contained about $10 \mathrm{~kg}$ of the nitrate mixtures. The carbon steel specimens were immersed at $316^{\circ} \mathrm{C}$ while the stainless steel specimens were immersed at $570^{\circ} \mathrm{C}$ with the exception of the ternary mixture. The ternary mixture was intentionally maintained at a low temperature because of uncertainty regarding its thermal stability. This crucible was held below $480^{\circ} \mathrm{C}$ for the first 5400 hours and then gradually increased to $550^{\circ} \mathrm{C}$ for the last 1600 hours. In all cases, crucible temperature was controlled to $\pm 10^{\circ} \mathrm{C}$. The melts were periodically sparged with air in order to maintain the nitrite concentration at the levels expected in solar thermal electric systems.

Two specimens of each alloy were removed from the nitrate mixtures at intervals of 120 , $264,480,832,1608,2952,4008$, and 7008 hours for examination and analysis. Two welded samples of each alloy were removed at 4008 hours. The $316 \mathrm{SS}$ coupons with 
TABLE I. Nominal composition and source of the constituents of each mixture examined in this study

\begin{tabular}{|c|c|c|}
\hline MLXTURE\# & COMPOSITION & SOURCE(GRADE) \\
\hline $\begin{array}{c}\# 1 \\
\text { (low chloride) }\end{array}$ & $\begin{array}{l}60 \% \mathrm{NaNO}_{3} \\
40 \% \mathrm{KNO}_{3}\end{array}$ & $\begin{array}{l}\text { Coastal } \\
\text { Coastal }\end{array}$ \\
\hline $\begin{array}{c}\# 2 \\
\text { (high chloride) }\end{array}$ & $\begin{array}{l}60 \% \mathrm{NaNO}_{3} \\
40 \% \mathrm{KNO}_{3} \\
+1.0 \text { wt. } \% \mathrm{NaCl}\end{array}$ & $\begin{array}{l}\text { Coastal } \\
\text { Coastal }\end{array}$ \\
\hline $\begin{array}{c}\# 3 \\
\text { (max. chloride) }\end{array}$ & $\begin{array}{l}60 \% \mathrm{NaNO}_{3} \\
40 \% \mathrm{KNO}_{3} \\
+1.3 \text { wt. } \% \mathrm{NaCl}\end{array}$ & $\begin{array}{l}\text { Coastal } \\
\text { Coastal }\end{array}$ \\
\hline$\# 4$ & $\begin{array}{l}60 \% \mathrm{NaNO}_{3} \\
40 \% \mathrm{KNO}_{3}\end{array}$ & $\begin{array}{l}\text { Chilean* (Technical) } \\
\text { Chilean }\end{array}$ \\
\hline$\# 5$ & $\begin{array}{l}60 \% \mathrm{NaNO}_{3} \\
40 \% \mathrm{KNO}_{3}\end{array}$ & $\begin{array}{l}\text { Chilean (Industrial) } \\
\text { Chilean }\end{array}$ \\
\hline$\# 6$ & $\begin{array}{l}60 \% \mathrm{NaNO}_{3} \\
40 \% \mathrm{KNO}_{3}\end{array}$ & $\begin{array}{l}\text { Chilean (Niterox) } \\
\text { Cedar } \S\end{array}$ \\
\hline \#7 & $\begin{array}{l}60 \% \mathrm{NaNO}_{3} \\
40 \% \mathrm{KNO}_{3}\end{array}$ & $\begin{array}{l}\text { Chilean (Technical) } \\
\text { Cedar }\end{array}$ \\
\hline$\# \mathrm{~T}^{0}$ & $\begin{array}{l}\mathrm{NaNO}_{3} \\
\mathrm{KNO}_{3} \\
\mathrm{Ca}\left(\mathrm{NO}_{3}\right)_{2}\end{array}$ & $\begin{array}{l}\text { Coastal } \\
\text { Coastal } \\
\text { Coastal }\end{array}$ \\
\hline \multicolumn{3}{|c|}{ 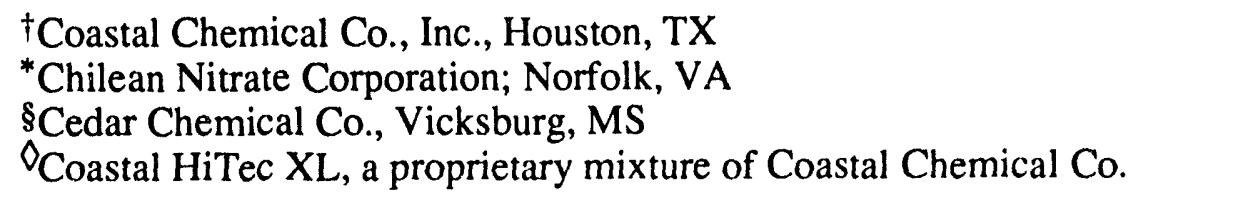 } \\
\hline
\end{tabular}


TABLE II. Impurity concentrations (wt.\%) in nitrate salt mixtures*

\begin{tabular}{|l||c|c|c|c|c|c|c|}
\hline Impurity & 1 & 2 & 3 & 4 & 5 & 6 & 7 \\
\hline Chloride & .040 & .574 & .760 & .260 & .462 & .104 & .060 \\
\hline Perchlorate & .035 & .032 & .045 & .247 & .316 & .140 & .064 \\
\hline Sulfate & $<.002$ & $<.002$ & $<.002$ & .146 & .182 & .015 & .011 \\
\hline Carbonate & .010 & .01 & .006 & .009 & .021 & .009 & .010 \\
\hline Nitrite & .025 & .028 & .027 & $<.001$ & .007 & .001 & $<.001$ \\
\hline
\end{tabular}

* Nominal salt composition: 60 wt.\% $\mathrm{NaNO}_{3} / 40$ wt.\% $\mathrm{KNO}_{3}$

TABLE III. Nominal elemental composition of alloys (wt. \%)

\begin{tabular}{|c||c|c|c|c|c|c|c|}
\hline Alloy & $\mathrm{C}$ & $\mathrm{Mn}$ & $\mathrm{Si}$ & $\mathrm{Cu}$ & $\mathrm{Mo}$ & $\mathrm{Cr}$ & $\mathrm{Ni}$ \\
\hline $\mathrm{A} \mathrm{36}$ & .29 & $.85-1.20$ & $.15-.30$ & .20 & - & - & - \\
\hline 304 SS & .08 & 2.0 & 1.0 & - & - & $18-20$ & $8-10$ \\
\hline 316 SS & .08 & 2.0 & 1.0 & - & $2.0-3.0$ & $16-18$ & $10-14$ \\
\hline
\end{tabular}


ground surfaces immersed in mixtures \#1, \#3, and \#6 were extracted at 4032 hours. Descaled weight loss was used as the principal measure of corrosion to avoid ambiguities caused by surface oxides that may not be completely adherent. The carbon steel coupons were descaled by immersing them in an inhibited hydrochloric acid solution at room temperature [11], while the stainless steel coupons were descaled in boiling alkaline permanganate [12]. These solutions removed all corrosion products with negligible attack of the underlying metal. In some instances, the companion specimens for selected time intervals were cross-sectioned and prepared for metallographic examination. Optical and scanning electron microscopy and electron microprobe analysis were used to characterize the structure and composition of the adherent corrosion products. The oxide phases present were identified by an X-ray diffraction procedure as described elsewhere [13].

\section{RESULTS AND DISCUSSION}

\section{Stainless Steels}

Descaled weight loss

Descaled weight loss measurements for the 316 SS coupons removed from the eight salt mixtures at various times are presented in Table IV. Double entries for a given time indicate that duplicate samples were descaled. The values for the duplicate entries indicate the variability in these measurements. The weight losses were between 5 and $6 \mathrm{mg} / \mathrm{cm}^{2}$ after 7008 hours of immersion, except for mixture \#6 which was somewhat higher at 8 $\mathrm{mg} / \mathrm{cm}^{2}$. The weight losses at 7008 hours correspond to reductions in metal thickness of 6 to 10 microns.

Figure 1a shows a plot of the average weight loss data vs. time for $316 \mathrm{SS}$. The close grouping of the weight loss curves for each of the salt mixtures indicates that corrosion of $316 S S$ was relatively insensitive to the impurity content of the various nitrate mixtures. The small descaled weight losses of coupons in the ternary salt mixture (\#T) were due to the low temperature of that crucible until near the end of the test. The average values of the descaled weight losses of $316 \mathrm{SS}$ are plotted in Figure $1 \mathrm{~b}$ using logarithmic coordinates. When plotted in this way, weight loss vs. time data can often be used to infer a corrosion mechanism. For example, data that exhibits a one-half power time dependence implies that the surface corrosion products grow by a diffusion-controlled process where the rate of formation slows as the oxide film thickens. Such a "parabolic" process is inherently protective since the formation of the scale impedes further corrosion. Alternatively, linear kinetics can arise in a number of ways. For example, the corrosion film may be porous and therefore not constitute an effective diffusion barrier. Net linear kinetics may arise through a sequential process of protective oxide layer growth and spallation.

In the present experiments, we are unable to assign a power-law (i.e., a unique kinetic process) to most of the data. In many of the mixtures, kinetics appear to closely follow parabolic rate laws initially and then become linear after prolonged exposures. This situation often arises when oxide layers grow until their adhesion is compromised, by the formation of residual stresses in the oxide layer for example [14]. In the absence of uniform corrosion kinetics for the entire duration of these tests, a conservative approach based on a linear extrapolation $f$ the data seems warranted for estimating corrosion-induced metal loss at longer times. For isothermal exposures, such linear extrapolations yield annualized weight losses of $6-10 \mathrm{mg} / \mathrm{cm}^{2}$. It should be recognized that in a solar thermal power application, the receiver is only at temperature approximately $1 / 3$ of the time. Thus, for a projected 30-year service life typical of solar thermal applications, an upper estimate of weight loss for $316 S S$ is $\approx 100 \mathrm{mg} / \mathrm{cm}^{2}$. This corresponds to a total metal loss for $316 \mathrm{SS}$ of 
Table IV. Descaled weight losses of 316 stainless steel coupons at $570^{\circ} \mathrm{C}$ for each salt mixture

\begin{tabular}{|c|c|c|c|c|c|c|c|c|}
\hline \multirow{2}{*}{$\begin{array}{c}\text { Time } \\
\text { (hours) }\end{array}$} & \multicolumn{8}{|c|}{ Weight loss $\left(\mathrm{mg} / \mathrm{cm}^{2}\right)$} \\
\hline & \#1 & \#2 & $\# 3$ & $\# 4$ & \#5 & \#6 & \#7 & \#T \\
\hline 120 & $\overline{0.38}$ & $\overline{0.50}$ & $\overline{0.53}$ & $\overline{0.60}$ & $\overline{0.67}$ & $\overline{0.45}$ & 0.40 & $\overline{0.03}$ \\
\hline 264 & 0.54 & 0.77 & $\overline{0.82}$ & 1.07 & 1.31 & 0.71 & 0.58 & 0.04 \\
\hline 432 & 0.65 & $\overline{0.89}$ & 1.14 & 1.40 & 1.78 & 0.96 & 0.74 & 0.01 \\
\hline 864 & 1.09 & 1.52 & 1.52 & 2.03 & 2.48 & 1.46 & 1.05 & $\overline{0.02}$ \\
\hline 1608 & 1.92 & 2.48 & 2.36 & 2.80 & $\overline{3.43}$ & 2.28 & 1.89 & $\overline{0.00}$ \\
\hline 2952 & 3.11 & 2.88 & 3.23 & $\overline{2.91}$ & 3.59 & 3.63 & 3.38 & 0.06 \\
\hline 2952 & 3.20 & 3.83 & 3.42 & 3.94 & 4.68 & 3.95 & 3.09 & $\overline{0.02}$ \\
\hline 4008 & 4.44 & 3.43 & 3.96 & 3.63 & 4.01 & 4.98 & 3.51 & 0.03 \\
\hline 4008 & 4.16 & 3.14 & 3.57 & 3.30 & 3.95 & 4.82 & 3.56 & $\overline{0.04}$ \\
\hline $4008 \mathrm{~W}$ & 4.09 & 3.37 & 4.14 & 3.69 & 4.31 & 4.18 & 3.10 & \\
\hline $4032^{*}$ & 2.60 & & 3.63 & & & 2.66 & & \\
\hline 7008 & 5.85 & 5.15 & 5.56 & 6.19 & 5.76 & 8.22 & 5.59 & 1.01 \\
\hline 7008 & & & & & & 8.69 & & \\
\hline
\end{tabular}

Note 1. Welded samples were immersed for 4008 hours. The weldment comprised about $20 \%$ of the coupons.

Note 2. 4032 hour specimens were prepared with a $\# 180$ grit ground surface finish.

Table V. Descaled weight losses of 304 stainless steel coupons at $570{ }^{\circ} \mathrm{C}$ for each salt mixture.

\begin{tabular}{|c|c|c|c|c|c|c|c|c|}
\hline \multirow{2}{*}{$\begin{array}{l}\text { Time } \\
\text { (hours) }\end{array}$} & \multicolumn{8}{|c|}{ Weight loss $\left(\mathrm{mg} / \mathrm{cm}^{2}\right)$} \\
\hline & \#1 & $\# 2$ & \#3 & $\# 4$ & $\# 5$ & \#6 & \#7 & \#T \\
\hline 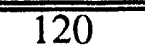 & $\overline{0 . \overline{94}}$ & $\overline{1.03}$ & 1.05 & 2.00 & $\overline{2.08}$ & 1.01 & 0.95 & $\overline{0.03}$ \\
\hline 264 & 0.99 & 1.18 & 1.29 & 2.06 & 2.25 & 1.20 & 1.09 & $\overline{0.03}$ \\
\hline 432 & 1.26 & 1.63 & 1.76 & 2.75 & 2.46 & 1.68 & 1.43 & $\overline{0.03}$ \\
\hline 864 & 1.52 & 2.19 & 2.68 & 3.95 & 4.40 & 2.15 & 1.70 & $\overline{0.02}$ \\
\hline 1608 & 2.11 & 3.89 & 5.82 & 4.48 & 5.34 & 2.85 & 2.26 & 0.04 \\
\hline 2952 & 2.71 & 4.49 & 4.57 & & 4.71 & 3.07 & 3.02 & 0.06 \\
\hline 2952 & 2.97 & 7.19 & 8.19 & 5.75 & 8.47 & $\overline{3.62}$ & 3.12 & 0.05 \\
\hline 4008 & 3.41 & 4.83 & 6.12 & 4.16 & 5.20 & 3.39 & 3.53 & 0.05 \\
\hline 4008 & 3.80 & 5.43 & 6.48 & 5.05 & 6.33 & $\overline{3.83}$ & 3.59 & 0.04 \\
\hline $4008 \mathrm{~W}$ & $3 . \overline{05}$ & 5.03 & $5 . \overline{26}$ & 4.40 & 5.55 & $\overline{3.20}$ & 3.06 & \\
\hline 7008 & 4.86 & 7.31 & 9.76 & 5.61 & 9.52 & 4.29 & 5.11 & 2.48 \\
\hline 7008 & & 7.47 & 7.98 & & 8.91 & & 4.53 & \\
\hline
\end{tabular}

Note 1. Welded samples were immersed for 4008 hours. The weldment comprised about $20 \%$ of the coupons. 

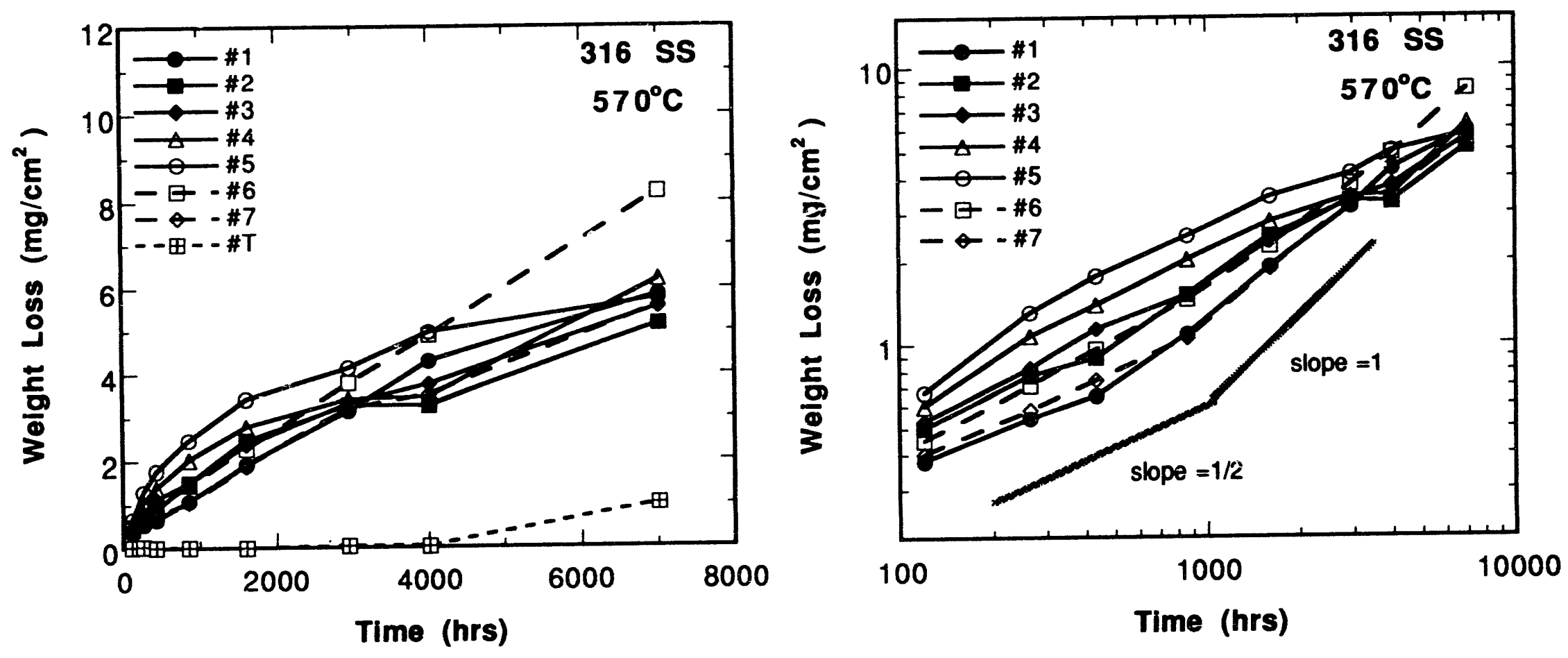

Figure 1. (a) Descaled weight loss measurements for 316 stainless steel specimens exposed to nitrate salt mixtures at $570^{\circ} \mathrm{C}$.

(b) Logarithmic plot of descaled weight loss measurements shown in (a). 
approximately $125 \mu \mathrm{m}(0.005 \mathrm{in})$. We emphasize that these estimates are based solely on the current isothermal exposure data and do not account for effects that may arise from the diurnal cycling inherent in receiver operation.

Descaled weight loss measurements for the 304SS coupons removed from the eight salt mixtures at various times are presented in Table $\mathrm{V}$ using the same format as Table IV. The average values of the descaled weight losses vs. time are plotted in Figure 2a. Overall, $304 S S$ exhibited more variability in corrosion resistance compared to $316 \mathrm{SS}$. The weight losses range from 4 to $10 \mathrm{mg} / \mathrm{cm}^{2}$ after 7000 hours of immersion or annualized losses of 5 to $12 \mathrm{mg} / \mathrm{cm}^{2}$. These weight losses correspond to an annualized reduction in metal thickness of 6 to $15 \mu \mathrm{m}$. For a 30-year service life, an upper estimate of total metal loss for 304SS is approximately $150 \mu \mathrm{m}(0.006 \mathrm{in})$. Again, the ternary mixture (\#T) was an exception because of the singularly low temperature in that crucible until late in the test.

The weight loss data for 304 SS reveal the presence of an effect due to chloride concentration. The effect is particularly evident for the high-purity mixture (\#1) vs. the chloride-doped mixtures, \#2 and \#3 (solid symbols in Figure 2). The mixtures containing a variety of impurities, \#4-7, also generally show increasing corrosion rates as chloride content increased, although other impurities, such as sulfate in mixture \#5, may also affect corrosion rates [15]. Those mixtures containing less than approximately $0.3 \mathrm{wt} . \%$ chloride, $\# 1$, \#6 and \#7, experienced $\approx 50 \%$ of the corrosion observed in the mixtures exceeding this level of chloride. We also note that corrosion rates of both 304SS and 316SS in the mixtures containing the lowest concentrations of impurities, \#1, \#6 and \#7, were essentially identical.

All of the 304SS coupons exhibited relatively large weight losses of $1-2 \mathrm{mg} / \mathrm{cm}^{2}$ within the first 100 hours of exposure, followed by much siower rates of weight loss. These initial weight losses may be attributed to the wire-brushed surface finish and are not typical of the bulk material response. In order to determine the corrosion kinetics for the data shown in Figure $2 \mathrm{a}$, it is necessary to normalize the data to remove the short-term weight losses. The normalization is performed by subtracting the time and weight loss measurements of the first exposure interval from all subsequent measurements. The relatively small weight losses, combined with the scatter in the data, precludes an unambiguous interpretation of Figure $2 b$, a logarithmic plot of the normalized data. The normalized data do, however, reveal certain interesting trends that further suggest the presence of a chloride effect. The coupons exposed to the higher chloride concentration mixtures (\#2-5) tend to exhibit nearly linear weight loss kinetics, although the rates are generally low. For the remaining low chloride binary mixtures (\#1, \#6 and \#7), the kinetics appear to more closely follow parabolic or one-half power time dependence. This can be seen more clearly in Figure 3 which shows a nearly linear relationship between descaled weight loss plotted against the square root of time (parabolic coordinates). This suggests that the corrosion scales formed in these low-chloride mixtures are protective. We suspect that the low linear corrosion rates in the higher chloride concentration mixtures are due to repeated detachment of otherwise protective oxides.

In addition to the effect of the wire-brushed surface finish on corrosion of $304 \mathrm{SS}$ described above, an effect of surface finish on corrosion of $316 \mathrm{SS}$ is suggested by the limited data in Table IV. In Table IV, weight losses are reported for three coupons of 316 SS that were prepared by grinding with \#180 grit carborundum paper. These coupons, tested in mixtures $\# 1$, \#3, and \#6 for 4032 hours, all experienced less weight loss than coupons with the asreceived, rolled surface finish. The response of the coupons with ground surfaces is expected to be more typical of the long-term corrosion behavior of the material. Although 

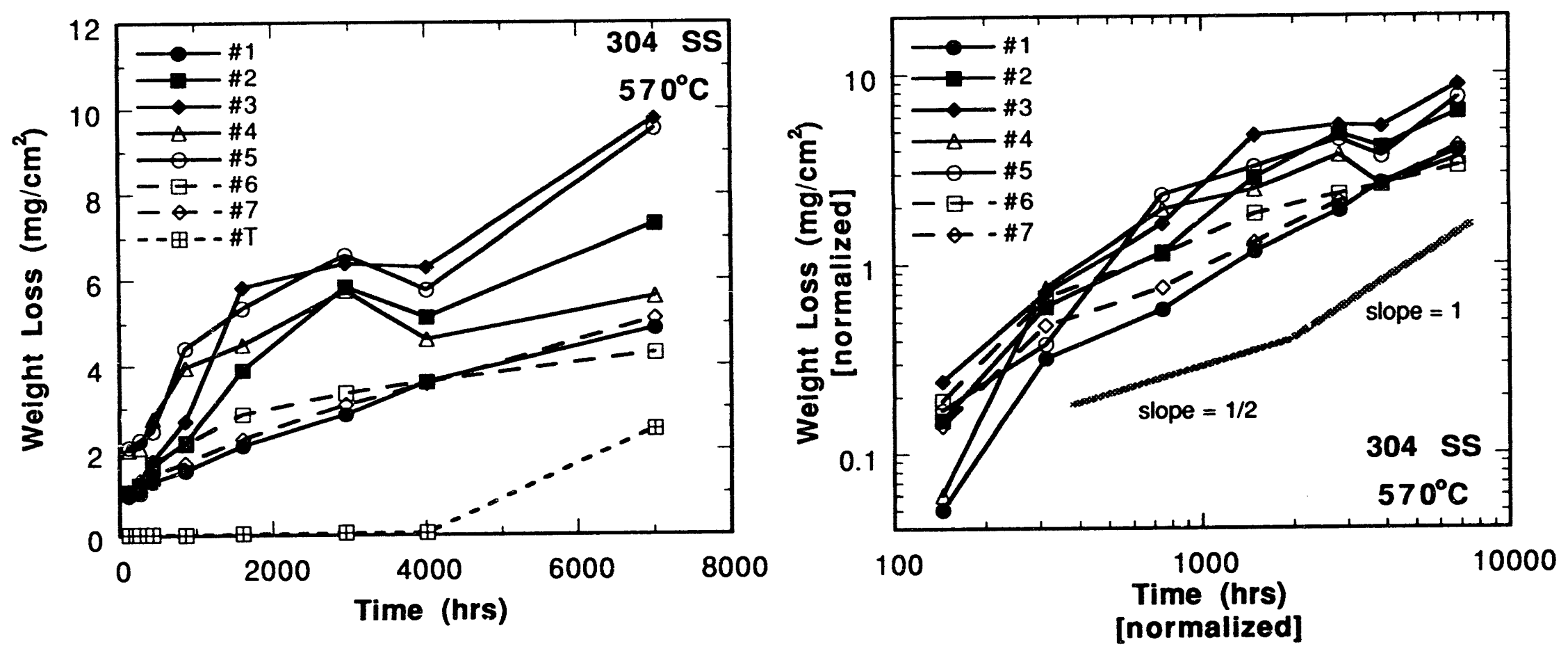

Figure 2. (a) Descaled weight loss measurements for 304 stainless steel specimens exposed to nitrate salt mixtures at $570^{\circ} \mathrm{C}$.

(b) Logarithmic plot of descaled weight loss measurements shown in (a). In order to eliminate surface effects, the data have been normalized to exclude weight loss measurements from the first sampling interval. 


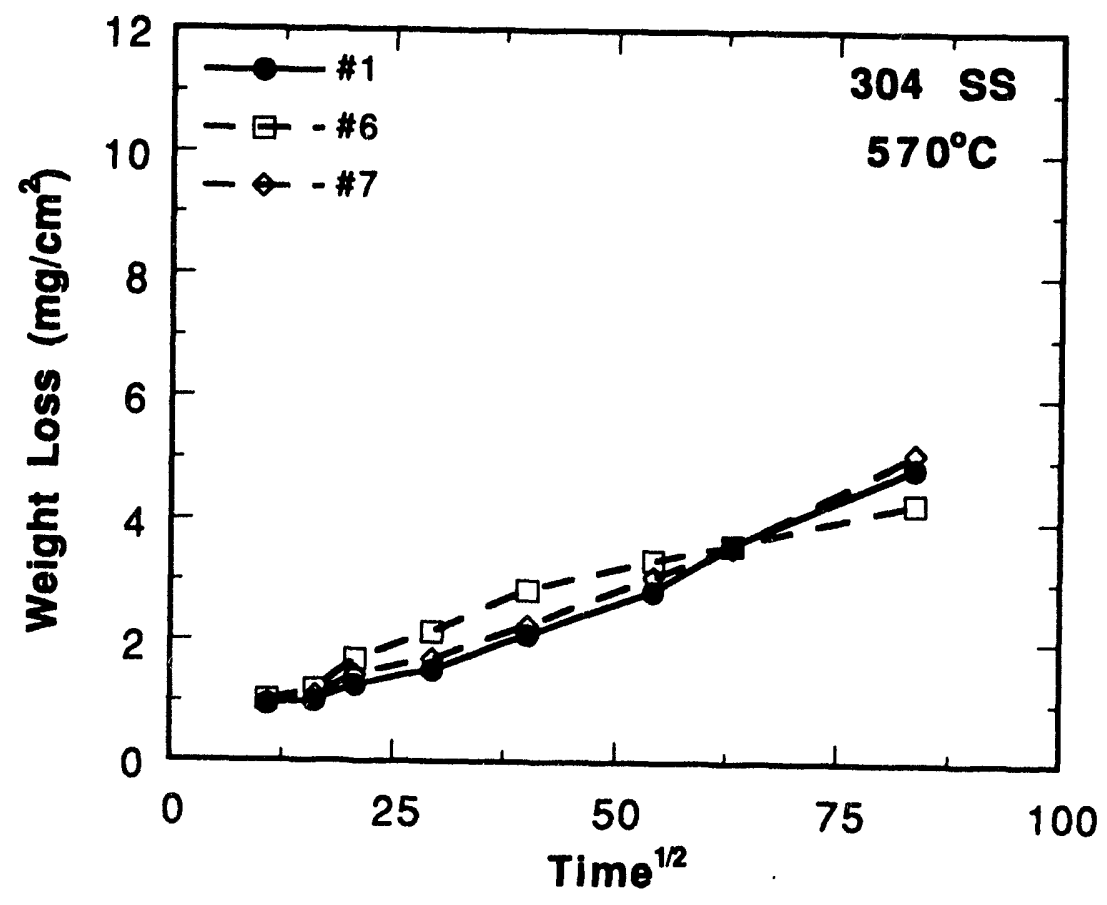

Figure 3. Descaled weight loss for 304 stainless steel specimens exposed to nitrate salt mixtures 1,6 and 7. After an initial rapid increase, weight loss measurements exhibit a parabolic dependence with respect to exposure time. 
grinding induces some localized cold work, it removes the more extensive work induced by rolling processes.

The data in Tables IV and V indicate that weldments of 316SS and 304SS, respectively, immersed for 4008 hours, generally corrode to the same extent as the parent metal. However, given the scatter in these data and the fact that the weld zones comprise only about $20 \%$ of the surface area of these coupons, it may not have been possible to detect any differences in weight changes unless the weld metal or heat-affected zones were very susceptible to corrosion. However, metallographic analysis of cross-sectioned segments of the weldments did not reveal any differences in corrosion behavior between the weld zones and the parent metal.

\section{Qxide adherence}

Visual inspection of the coupons before descaling clearly indicated that the surface oxide layers spalled to some degree on most samples. In many cases it was clear that the unoxidized base metal was visible, indicating that spallation had occurred upon cooling to room temperature. As a means to objectively compare the tendencies of oxide layers to spall from each steel in various salt mixtures, the following quantitative indicator was used. We define $S$ to be the ratio of the net weight gain (the weight of a coupon upon removal from the crucibles minus its initial weight) and the descaled weight loss. If all of the oxide formed by corrosion adheres to a coupon and if the loss of soluble metal alloy constituents to the melt is negligible, then the value of $S$ is established by the stoichiometry of the oxide according to Equation 1.

$S=\frac{g_{0}^{*} W_{(\mathrm{a} / \mathrm{o})} \text { Oxygen }}{\mathrm{gM}_{\mathrm{M}}^{*} \mathrm{~W}_{(\mathrm{a} / \mathrm{o})} \text { Metal }}$

In Equation 1, the values of $g$ are the stoichiometric coefficients of oxygen and metal in the oxide scale and $\mathrm{W}_{(\mathrm{a} / \mathrm{o})}$ their respective atomic weights. Based on the $\mathrm{X}$-ray diffraction results discussed later, we can assume that magnetite, $\mathrm{Fe}_{3} \mathrm{O}_{4}$, constitutes the major fraction of the oxide formed. Since the alloying elements in 304SS and 316SS are all transition metals with similar atomic weights, we neglect the effect on $\mathrm{W}_{(\mathrm{a} / \mathrm{o})}$ Metal and use the value for iron (55.6). For this case, the value of $S$ is 0.38 . To obtain an indicator of oxide adherence that varies between unity for completely adherent layers and zero for completely detached oxides, we note that for completely adherent oxides, the weight of a coupon as removed from the melt, $\mathrm{W}_{\mathrm{f}}$, is

$\mathrm{W}_{\mathrm{f}}=\mathrm{W}_{\mathrm{o}}+S * \Delta \mathrm{Wloss}$

where $W_{0}$ is the initial coupon weight.

To obtain a quantity on the left-hand side that becomes zero if all the oxide spalls off, we subtract the weight of the descaled coupon, $\mathrm{W}_{\mathrm{d}}$, from each side.

$\left(\mathrm{W}_{\mathrm{f}}-\mathrm{W}_{\mathrm{d}}\right)=\left(\mathrm{W}_{\mathrm{o}}-\mathrm{W}_{\mathrm{d}}\right)+S * \Delta \mathrm{Wloss}=(S+1) * \Delta \mathrm{Wloss}$

The above equation can be rearranged into an identity that we define as the oxide adherence indicator, $Y$. 
$Y=\frac{1}{S+1} \frac{\left(W_{\mathrm{f}}-\mathrm{W}_{\mathrm{d}}\right)}{\Delta \mathrm{Wloss}}$

We expect that oxides should be adherent at least at short times, so the sampling time at which $Y$ decreases below unity indicates that oxide spallation has occurred. Since weight change measurements are aggregated over the entire coupon, the value of the indicator gives no information about the type of spallation and it is not necessarily useful for mechanistic interpretations of spalling. Specifically, the oxide adherence factor, $Y$, does not address the inherent adherence of the suriace scales as they are formed during the exposure of the alloy to the nitrate salts. Values less than unity do not serve to indicate that spallation occurs concurrently with the high temperature exposure or at some time subsequent to exposure. Further, these data afford us no information regarding how spalling progresses once the initial detachment of some or all of the scale occurs.

The calculated values of $Y$ for 316SS and 304SS are shown in Tables VI and VII, respectively. Table VI shows that the oxide layers on 316SS are adherent in virtually all the salt mixtures for at least 1600 hours. At the next sampling interval (2952 hours), these values decline below unity in all cases. This result correlates with the weight loss measurements in Figures $1 \mathrm{a}$ and $\mathrm{b}$ in that parabolic kinetics are obeyed at short time intervals while linear kinetics hold for longer-term exposures. The data for 316SS show that the coupons with ground surfaces placed in mixtures \#1 and \#6 had adherent scale layers at 4032 hours, while the sample in mixture \#3 spalled. This implies that by removing metal from the surface, the grinding process can enhance oxide adherence. Since the former mixtures were the lowest in chloride content, while \#3 had the highest chloride content, it appears that the presence of chloride degrades oxide adhesion in molten nitrate salts (as it does in other oxidizing environments [6]) even on ground surfaces.

In contrast to 316 SS, Table VII shows that even at 100 hours, the oxide layers on 304SS were not completely adherent. The lack of oxide adherence indicated in Table VII is not inconsistent with the parabolic weight change data for 304SS shown in Figure 3 for mixtures \#1, \#6, and \#7. Rather, these two observations suggest that the loss in oxide adherence results from thermal stresses induced upon specimen cooling to room temperature.

\section{Oxide structure and composition}

Detailed characterization of the structure and evolution of the corrosion products was made difficult due to the degree of spallation that occurred and by the complexity of the surface oxidation products. However, a number of coupons had remnants of oxide scales that provided useful information regarding structure. Figure 4 shows a scanning electron micrograph of a metallographic cross-section of a $304 S S$ coupon immersed in mixture \#4 for 1608 hours. The coupon was nickel plated prior to metallographic preparation (in order to protect the corrosion products from damage) and the layer of plating is marked on the micrograph. The microscopy reveals that the oxide has formed a surface film with an average thickness of $5-12 \mu \mathrm{m}$. The scale in Figure 4 is comprised of two distinct regions separated by a well-defined crack that runs parallel to the oxide-metal interface. The scale formed at the external surface (adjacent to the nickel layer) is the most irregular in thickness, varying from 1 to $8 \mu \mathrm{m}$. The variability in the thickness of the oxide reflects the lack of adherence (it is likely that the structure shown is not a first generation scale). While the oxide adjacent to the alloy is considerably more uniform in thickness, it appears to be quite porous. The general morphology of the corrosion products shown in this figure was characteristic of those formed in each of the binary salt mixtures. However, the extensive 
Table VI. Oxide adherence on 316 stainless steel coupons at $570^{\circ} \mathrm{C}$ for each salt mixture.

\begin{tabular}{|c||c|c|c|c|c|c|c|c|}
\hline \multirow{2}{*}{$\begin{array}{c}\text { Time } \\
\text { (hours) }\end{array}$} & \multicolumn{8}{|c|}{ Oxide adherence indicator } \\
\hline \hline 120 & 0.99 & 0.94 & 0.96 & 1.00 & 0.97 & 0.97 & 0.96 & Note 2 \\
\hline 264 & 1.00 & 0.98 & 0.94 & 0.99 & 0.96 & 1.00 & 0.96 & \\
\hline 432 & 0.97 & 0.98 & 0.90 & 0.93 & 0.94 & 0.94 & 0.93 & \\
\hline 864 & 0.94 & 1.01 & 0.98 & 0.93 & 0.93 & 0.72 & 0.92 & \\
\hline 1608 & 0.60 & 0.94 & 0.62 & 0.91 & 0.89 & 0.46 & 0.62 & \\
\hline 2952 & 0.85 & 0.90 & 0.88 & 0.66 & 0.83 & 0.78 & 0.79 & \\
\hline 2952 & 0.84 & 0.94 & 0.90 & 0.58 & 0.81 & 0.72 & 0.79 & \\
\hline 4008 & 0.90 & 0.83 & 0.64 & 0.55 & 0.78 & 0.77 & 0.93 & \\
\hline 4008 & 0.90 & 0.69 & 0.76 & 0.55 & 0.79 & 0.78 & 0.94 & \\
\hline $4008 \mathrm{~W}$ & 0.85 & 0.54 & 0.72 & 0.51 & 0.70 & 0.69 & 0.78 & \\
\hline 4032 & 1.04 & & 0.52 & & & 1.00 & & \\
\hline 7008 & 0.74 & 0.59 & 0.54 & 0.44 & 0.51 & 0.67 & 0.63 & \\
\hline 7008 & & & & & & 0.66 & & \\
\hline
\end{tabular}

Note 1. Welded samples were immersed for 4008 hours. Weldments comprised about $20 \%$ of the specimens.

Note 2. Values were not calculated for the ternary mixture since it was not at $570^{\circ} \mathrm{C}$.

Note 3. Coupons ground with 180-grit carborundum paper were immersed for 4032 hours in mixtures \#1, \#3, and \#6.

Table VII. Oxide adherence on 304 stainless steel coupons at $570^{\circ} \mathrm{C}$ for each salt mixture.

\begin{tabular}{|c||c|c|c|c|c|c|c|c|}
\hline \multirow{2}{*}{$\begin{array}{c}\text { Time } \\
\text { (hours) }\end{array}$} & \multicolumn{9}{|c|}{ Oxide adherence indicator } \\
\hline \hline 120 & 0.69 & 0.69 & 0.73 & 0.88 & 0.88 & 0.68 & 0.66 & n.a. \\
\hline 264 & 0.69 & 0.73 & 0.73 & 0.91 & 0.93 & 0.71 & 0.68 & \\
\hline 432 & 0.70 & 0.74 & 0.73 & 0.88 & 0.92 & 0.71 & 0.69 & \\
\hline 864 & 0.74 & 0.67 & 0.80 & 0.86 & 0.85 & 0.75 & 0.74 & \\
\hline 1608 & 0.74 & 0.75 & 0.82 & 0.85 & 0.81 & 0.78 & 0.74 & \\
\hline 2952 & 0.76 & 0.69 & 0.79 & 0.83 & 0.70 & 0.78 & 0.76 & \\
\hline 2952 & 0.75 & 0.70 & 0.76 & -- & 0.76 & 0.81 & 0.73 & \\
\hline 4008 & 0.78 & 0.64 & 0.80 & 0.84 & 0.69 & 0.79 & 0.76 & \\
\hline 4008 & 0.76 & 0.72 & 0.68 & 0.84 & 0.75 & 0.81 & 0.78 & \\
\hline $4008 \mathrm{~W}$ & 0.80 & 0.68 & 0.74 & 0.76 & 0.74 & 0.80 & 0.80 & \\
\hline 7008 & 0.80 & 0.50 & 0.64 & 0.83 & 0.70 & 0.79 & 0.81 & \\
\hline 7008 & & 0.42 & 0.68 & & 0.62 & & 0.79 & \\
\hline
\end{tabular}

See notes 1 and 2 above. 


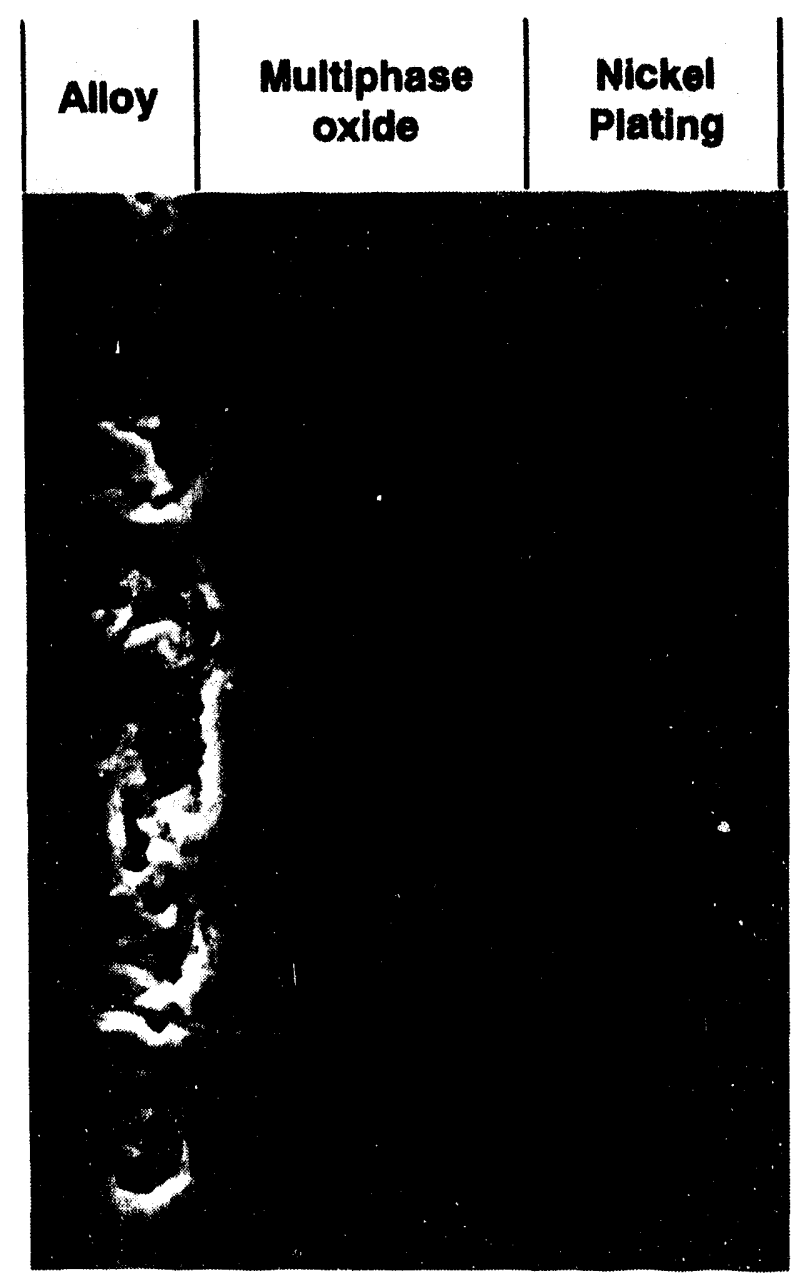

Figure 4. Shows a scanning electron micrograph of a metallographic cross-section of a 304SS coupon immersed in mixture \#4 for 1608 hours. 
porosity at the oxide-metal interface evident in Figure 4 was only occasionally observed. It was not seen in any of the 304SS coupons at times shorter than 1608 hours and was observed in the 316SS specimens at only much longer times. This porosity may explain the lack of adherence of the corrosion products. The fact that this porosity is only occasionally observed suggests it develops slowly with time as each successive generation of oxide is formed.

Figure 5 shows a backscatter electron image (BSE) of the adherent oxide on a 304SS coupon immersed in mixture \#1 for 7008 hours. The contrast in the corrosion layer reflects the sensitivity of BSE to the atomic mass of the constituents of the different oxide phases. The figure also shows the elemental distribution of the principal alloying elements of 304SS and certain constituents of the nitrate mixture [16], sodium and magnesium, through the thickness of the surface scale. This analysis was done using the wavelength dispersive analysis (WDS) capability of the electron microprobe (EMP) and is semi-quantitative in nature. Because of the extensive spallation, neither the image nor the elemental profiles reflect the structure and composition of a 7000 hour oxide. Rather, they only reflect the residual, adherent structure of an " $n^{\text {th }}$ " generation scale. Thus, these elemental profiles can show considerable variation between specimens. For the corrosion features shown in Figure 5, the WDS results reveal that the oxide at the external surface (the surface in contact with the salt) was a chromium-free, iron-based oxide that contained $\approx 12 \%$ sodium. This is typical of many of the residual oxides at this and at shorter time intervals and has been observed in an earlier study [17]. X-ray diffraction (see below) identified this surface scale as $\mathrm{NaFeO}_{2}$. The analysis further revealed that iron and chromium were the principal metallic constituents of the subsurface scale. Manganese was also found in this layer at 2-3 times its normal concentration in the alloy. Chemical analysis revealed that mixture \#1 contained only trace amounts of magnesium and in agreement with this, no magnesium was detected in any of the oxide layers.

Figure 6 shows an example of the oxide structure formed on a 304SS coupon immersed in mixture \#4 for 7008 hours and the associated EMP ana.ysis. Generally, the oxide exhibits similar features to that shown previously. In this case, though magnesium was found in the surface oxide layer at concentrations less than $\approx 5 \mathrm{wt}$. \%. Sodium appears to be somewhat more uniformly distributed throughout the entire oxide structure. Figure 7 shows the oxide structure formed on a 7008 hour coupon of 304SS immersed in mixture \#6. In this instance, the micrograph suggests the presence of three distinct oxide layers. The associated elemental profiles through the oxide are also shown in Figure 7 and reveal that the near surface layer is comprised of iron and magnesium $(\approx 8 \% \mathrm{Mg})$.

$\mathrm{X}$-ray diffraction was used to identify specific crystallographic phases in the oxide structures. The analyses focused primarily on samples removed from mixtures \#1 and \#5 at progressively longer sampling times up to 2952 hours. Three major phases were identified on both alloys. These consisted of an orthorhombic $\mathrm{Fe}_{2} \mathrm{O}_{3}$ (hematite) type phase, a cubic spinel $\mathrm{Fe}_{3} \mathrm{O}_{4}$ (magnetite) type and orthorhombic sodium ferrite, $\mathrm{NaFeO}_{2}$. The sodium ferrite may have its origin in the reaction between trace amounts of sodium oxide in the molten nitrate and hematite as:

$$
\mathrm{Na}_{2} \mathrm{O}+\mathrm{Fe}_{2} \mathrm{O}_{3} \rightarrow 2 \mathrm{NaFeO}_{2}
$$

Based on the corresponding EMP data, chromium and manganese likely substitute for iron in the cubic spinel oxide corresponding to an $(\mathrm{Fe}, \mathrm{Cr}, \mathrm{Mn})_{3} \mathrm{O}_{4}$ type structure. In addition, it is likely that substitution of magnesium (when present) and chromium for iron in the spinel $\mathrm{Fe}_{3} \mathrm{O}_{4}$ phase corresponds to a $(\mathrm{Fe}, \mathrm{Cr}, \mathrm{Mg}) \mathrm{O}_{4}$ type cubic structure. Where magnesium is detected, it is likely that $\mathrm{Mg}^{+2}$ substitutes for $\mathrm{Fe}^{+2}$ in $\mathrm{Fe}_{3} \mathrm{O}_{4}$ to form $\mathrm{MgFe}_{2} \mathrm{O}_{4}$. 

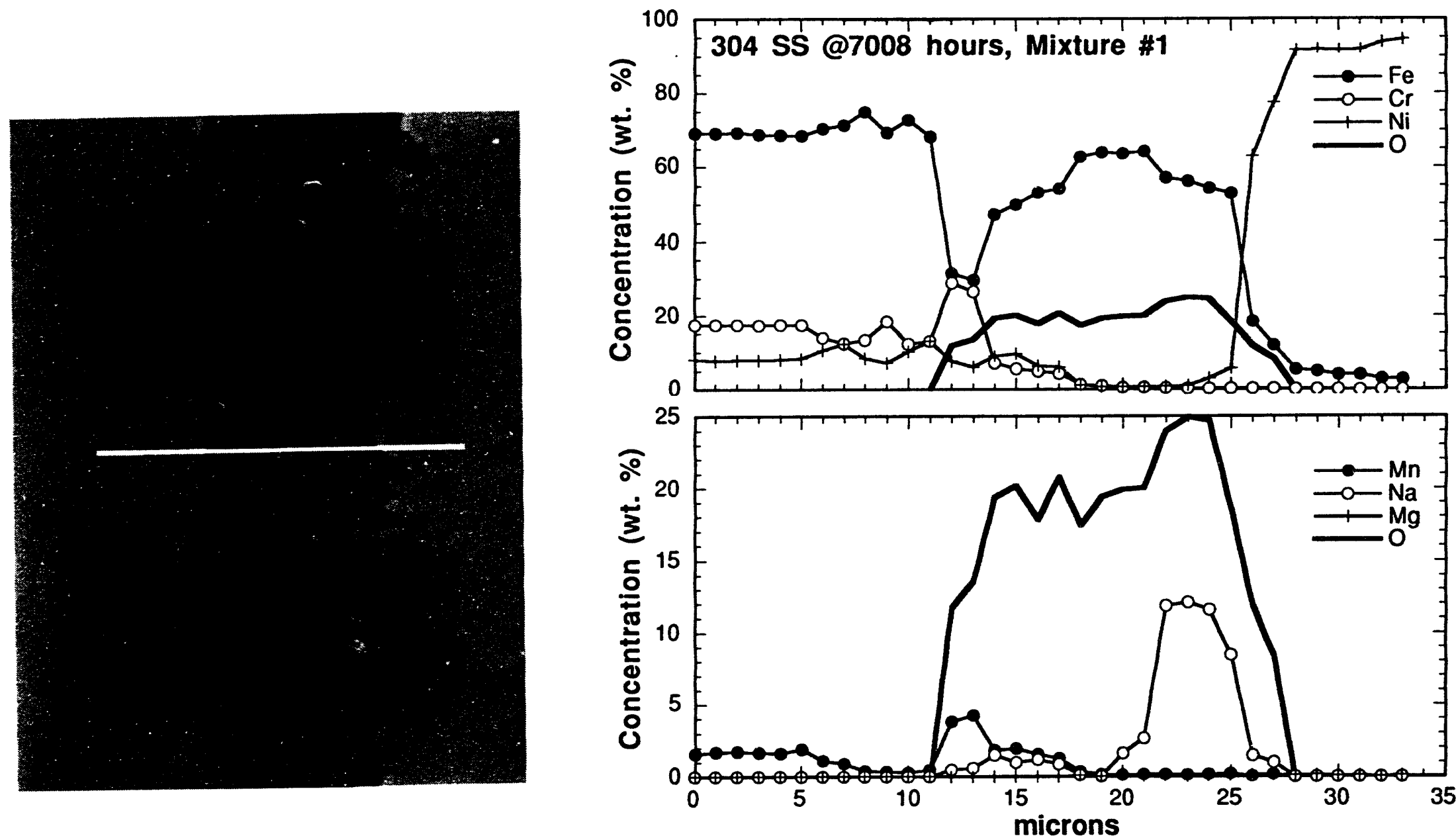

Figure 5. Shows a backscatter electron image (BSE) of the adherent oxide on a 304SS coupon immersed in mixture \#1 for 7008 hours. 

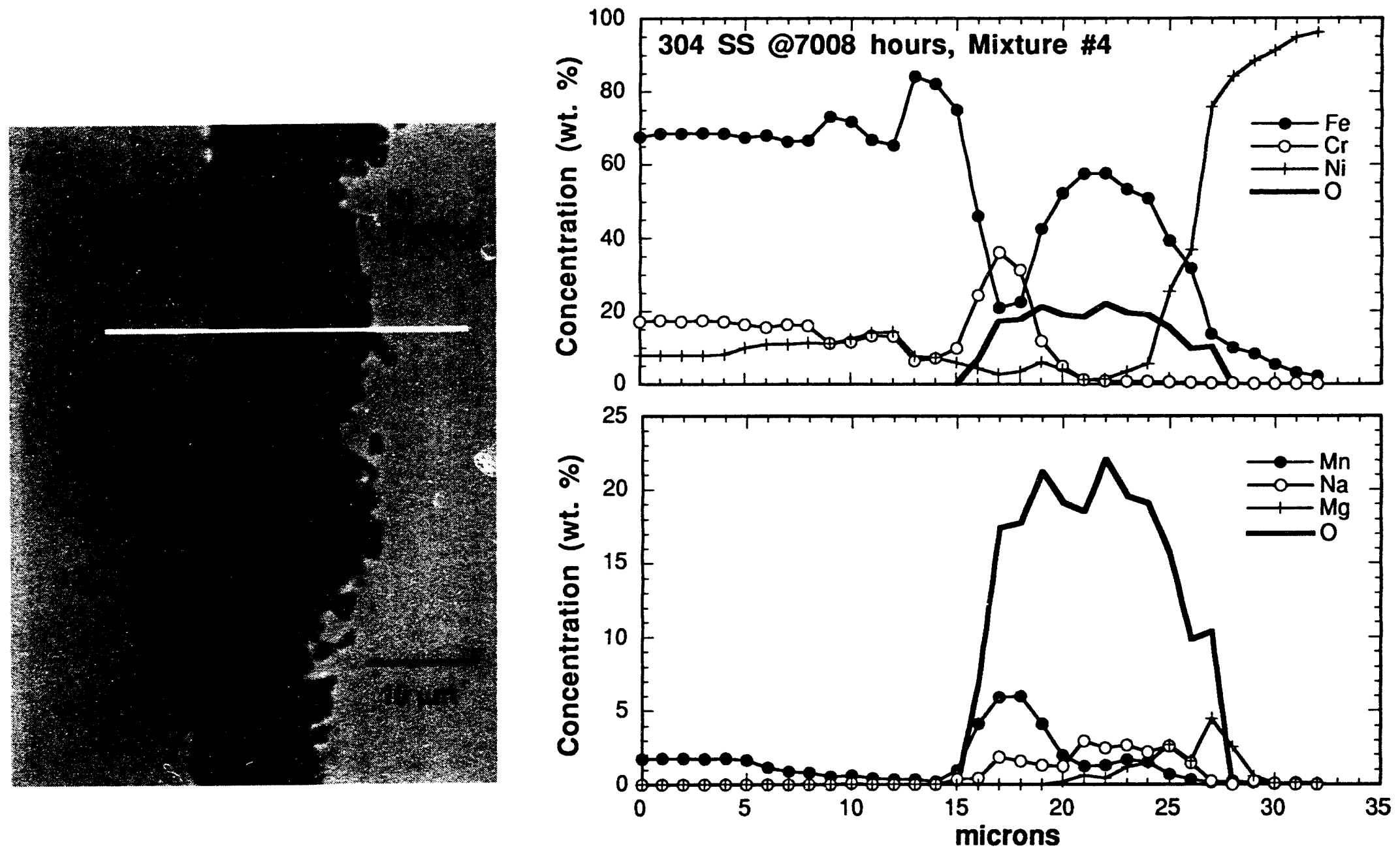

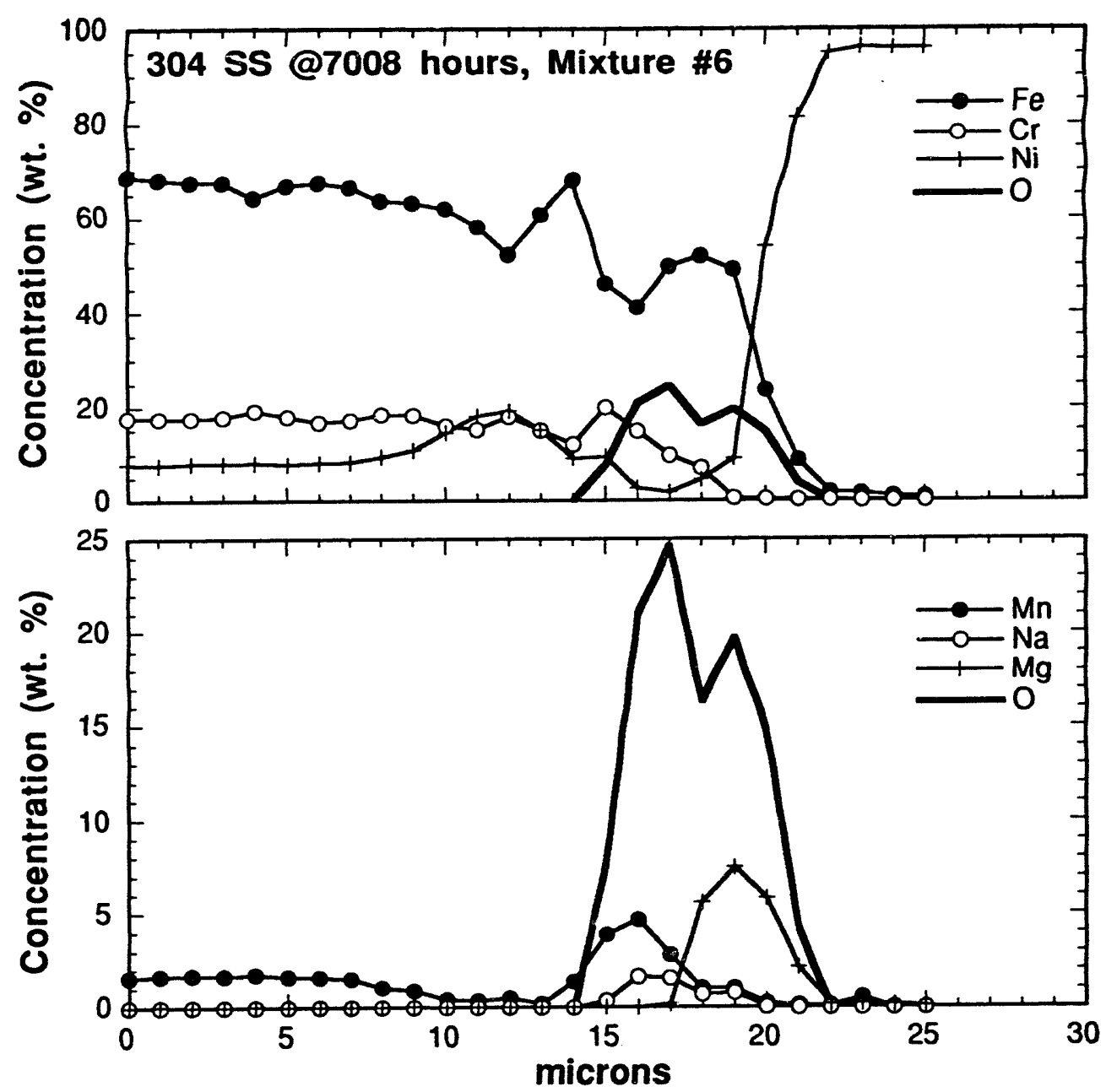

Figure 7. Shows the oxide structure formed on a 7008 hour coupon of 304SS immersed in mixture \#6. 

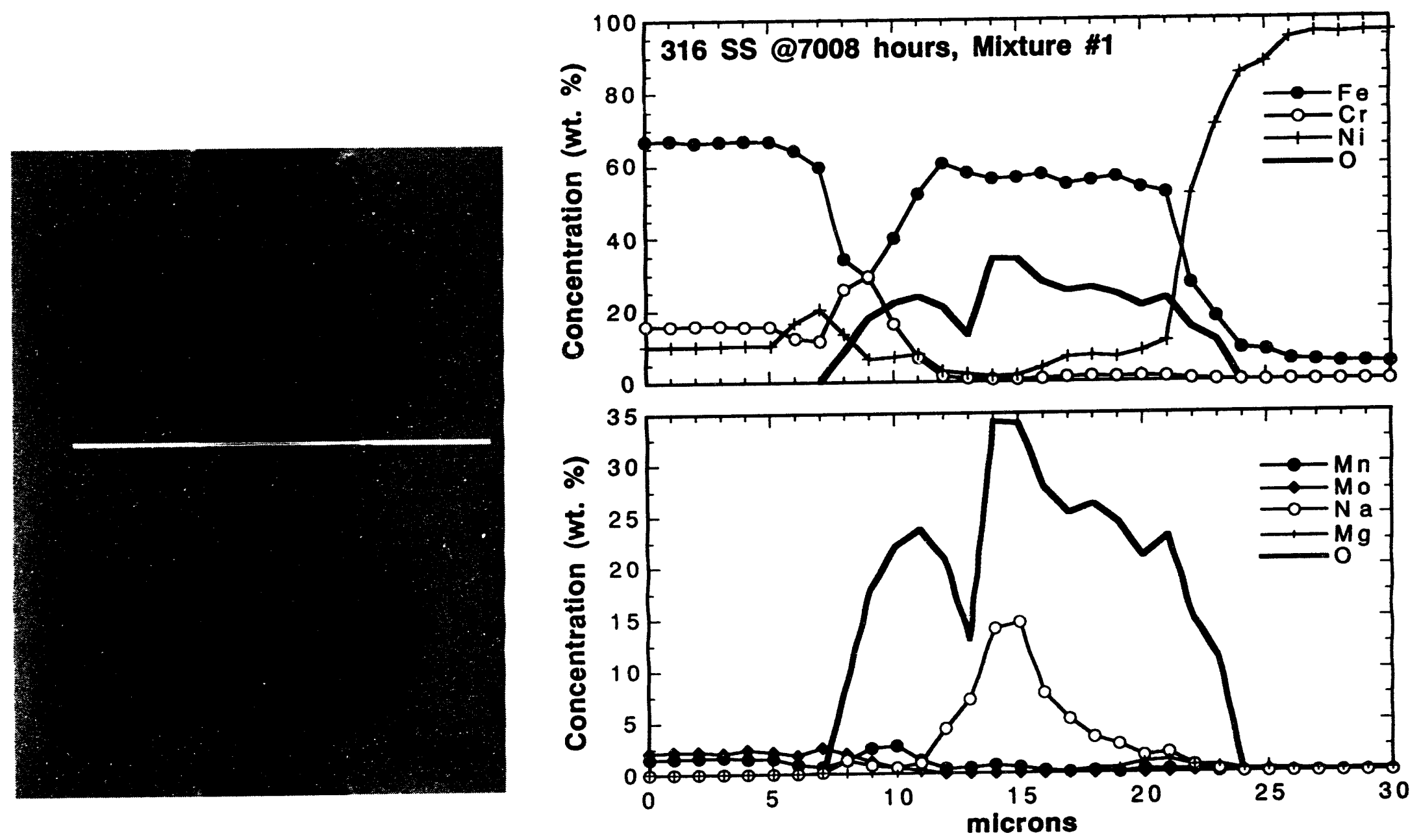

Figure 8. Shows an example of the oxide structure formed on a 316SS coupon immersed in mixture \#1 for 7008 hours and the associated EMP analysis. 
Coupons immersed in mixtures \#4 and \#5 had surface scales with a distinctive rust-red coloration indicative of hematite $\left(\mathrm{Fe}_{2} \mathrm{O}_{3}\right)$. The relative abundance of the different phases changed with immersion time. For instance, the XRD results for the samples immersed for 864 hours identified the presence of both the $\mathrm{Fe}_{2} \mathrm{O}_{3}$ and $\mathrm{Fe}_{3} \mathrm{O}_{4}$ type of oxides. At this sampling interval, $\mathrm{Fe}_{2} \mathrm{O}_{3}$ was more abundant compared to $\mathrm{Fe}_{3} \mathrm{O}_{4}$, based on relative intensity of the diffraction peaks. The $\mathrm{Fe}_{3} \mathrm{O}_{4}$ phase increased with respect to $\mathrm{Fe}_{2} \mathrm{O}_{3}$ as exposure time increased. $\mathrm{NaFeO}_{2}$ was first observed for the $1608 \mathrm{hr}$ samples (both 304 and 316SS) and was most abundant in the samples removed from mixture \#5. Furthermore, the $\mathrm{NaFeO}_{2}$ phase continued to increase in samples removed at 2952 hours. Because of the extensive spallation, $\mathrm{X}$-ray analysis was not performed at longer immersion times. Even at shorter times, the observations regarding the relative abundance of the different oxide phases must be considered qualitative.

All of the 304SS coupons exhibited the presence of dark subsurface features located in a 5 micron wide band immediately below the oxide-metal interface. In each instance, these features are associated with elevated nickel concentrations $(\approx 14-20 \mathrm{wt} . \%)$ and depleted chromium concentrations $(\approx 12 \%)$. At this writing, work is in progress to identify the structure and composition of these features.

Figure 8 shows an example of the oxide structure formed on a 316SS coupon immersed in mixture \#1 for 7008 hours and the associated EMP analysis. Once again, the oxide exhibits similar features to that shown previously. In this case, the surface scale is revealed to be striated, consisting of many successive layers of different oxide phases. The spatial resolution of the WDS technique is inadequate to qualitatively reveal the composition of each individual oxide layer. In this particular case, the analysis reveals that the layer consisting predominantly of the $\mathrm{NaFeO}_{2}$ phase is located intermediately between surface iron oxides and an iron-chromium spinel at the metal interface.

\section{Carbon Steel}

\section{Descaled weight loss}

Descaled weight loss measurements for the carbon steel specimens at $316^{\circ} \mathrm{C}$ are shown in Table VIII and Figure 9a. In general, the data fall into two distinct categories. The specimens exposed to the high-purity/chloride-doped mixtures (\#1-3) experienced both larger initial weight losses and larger long-term weight losses than coupons immersed in mixtures \#4-7, which contained a variety of impurities in addition to chloride. Chloride concentration alone cannot account for these differences in corrosivity since the chloride levels of mixtures \#4-7 were intermediate between mixtures \#1 and \#2 (see Table I). Indeed, even for those specimens immersed only in mixtures \#1, \#2 and \#3, where the base nitrate composition was identical, the increasing chloride concentration did not result in an unambiguous increase in corrosion. For the specimens exposed to nitrate mixtures containing other impurities (\#'s 4-7), the overall weight changes do not show a systematic effect of chloride levels on corrosion.

These observations contrast with previous findings of short-term corrosion tests. For example, El Hosary, et al. [8], reported that the corrosion rate of mild stcel at $400^{\circ} \mathrm{C}$ increased approximately as the logarithm of the chloride concentration in the range studied here. In that work, at $0.5 \mathrm{wt} . \%$ chloride, the corrosion rate increased by a factor of about three compared to a chloride-free melt during an 8-hour test. Notoya, et al, report substantially the same results for corrosion of iron at $400-450^{\circ} \mathrm{C}[10]$. The lower temperatures employed in the current work may be the source of the contrasting behavior. 
Table VIII. Descaled weight losses of A36 carbon steel coupons at $316^{\circ} \mathrm{C}$ for each salt mixture.

\begin{tabular}{|c|c|c|c|c|c|c|c|c|}
\hline \multirow{2}{*}{$\begin{array}{l}\text { Time } \\
\text { (hours) }\end{array}$} & \multicolumn{8}{|c|}{ Weight loss $\left(\mathrm{mg} / \mathrm{cm}^{2}\right)$} \\
\hline & \#1 & $\# 2$ & \#3 & $\# 4$ & $\# 5$ & \#6 & \#7 & $\# T$ \\
\hline 120 & 0.45 & $\overline{0.51}$ & 0.54 & 0.28 & $\overline{0.30}$ & $\overline{0.23}$ & $\overline{0.25}$ & $\overline{0.22}$ \\
\hline 264 & 0.64 & 0.70 & 0.73 & 0.37 & $0 . \overline{37}$ & 0.33 & 0.34 & 0.22 \\
\hline 432 & 0.64 & 0.68 & 0.70 & 0.39 & 0.46 & 0.36 & 0.38 & 0.21 \\
\hline 864 & 0.86 & 0.83 & 0.83 & 0.41 & 0.45 & 0.47 & $0.4 !$ & 0.20 \\
\hline 1608 & 1.72 & 1.88 & 1.40 & 0.56 & 0.60 & 0.47 & 0.66 & 0.32 \\
\hline 2952 & 1.51 & 1.40 & 1.91 & 0.57 & 0.89 & 0.57 & 0.86 & 0.28 \\
\hline 4008 & 2.07 & 3.06 & 1.43 & 0.70 & 0.86 & 0.73 & 1.02 & 0.40 \\
\hline 4008 & 2.39 & 2.26 & 1.56 & 0.76 & 1.02 & 0.76 & 0.84 & -- \\
\hline $4008 W$ & 2.34 & 1.92 & 1.40 & 1.18 & 1.21 & 1.13 & 1.24 & $\overline{--}$ \\
\hline 7008 & 2.32 & 3.14 & 2.05 & 0.79 & 0.88 & 0.94 & 0.99 & 0.28 \\
\hline
\end{tabular}

Note 1. ' $4008 \mathrm{~W}$ ' designates welded samples that were immersed to 4008 hours before descaling. The weldment comprised about $20 \%$ of the sample.

Table IX. Oxide adherence on A36 carbon steel coupons at $316^{\circ} \mathrm{C}$ for each salt mixture.

\begin{tabular}{|c||c|c|c|c|c|c|c|c|}
\hline \multirow{2}{*}{$\begin{array}{c}\text { Time } \\
\text { (hours) }\end{array}$} & \multicolumn{10}{|c|}{ Oxide adherence indicator } \\
\hline \hline 120 & 0.87 & 0.91 & 0.91 & 0.95 & 0.81 & 0.9 & 1.01 & Note 2 \\
\hline 264 & 0.93 & 0.95 & 0.95 & 1.00 & 0.98 & 0.96 & 0.99 & \\
\hline 432 & 0.93 & 0.93 & 0.95 & 1.00 & 0.93 & 0.97 & 0.98 & \\
\hline 864 & 0.95 & 0.96 & 0.96 & 1.04 & 1.04 & 1.01 & 1.02 & \\
\hline 1608 & 0.94 & 0.95 & 0.95 & 1.01 & 0.99 & 1.03 & 1.03 & \\
\hline 2952 & 0.95 & 0.93 & 0.91 & 1.06 & 1.00 & 1.06 & 0.99 & \\
\hline 4008 & 0.94 & 0.93 & 0.92 & 1.09 & 0.98 & 1.03 & 0.97 & \\
\hline 4008 & 0.94 & 0.93 & 0.93 & 0.99 & 0.97 & 1.08 & 1.04 & \\
\hline $4008 W$ & 0.84 & 0.84 & 0.85 & 0.85 & 0.85 & 0.87 & 0.86 & \\
\hline 7008 & 0.94 & 0.83 & 0.91 & 1.06 & 1.11 & 1.09 & 1.08 & \\
\hline
\end{tabular}

Note 1. Welded samples were immersed for 4008 hours. The weldment comprised about $20 \%$ of the specimens.

Note 2. These values were not calculated for the irrnary salt mixture since the oxide layer formed was different from that used as the basis of the calculation (magnetite). 

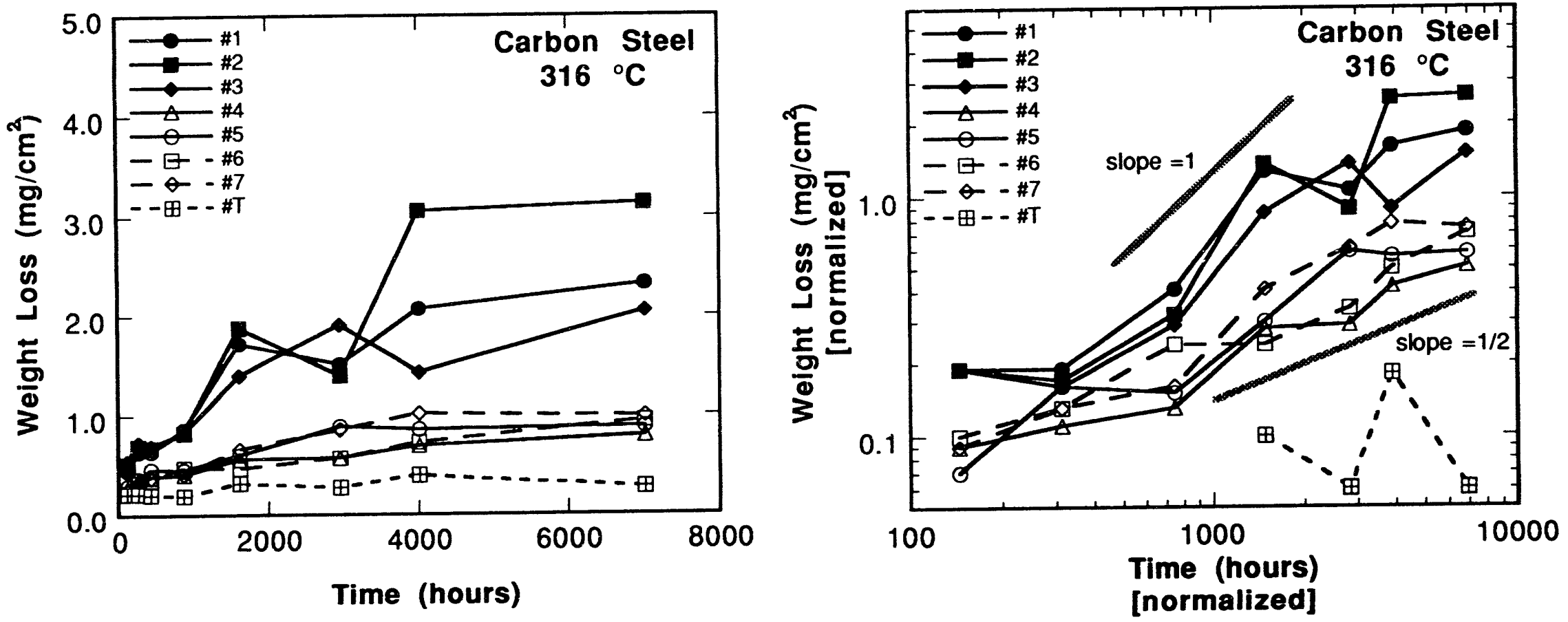

Figure 9. (a) Descaled weight loss measurements for carbon steel specimens exposed to nitrate salt mixtures at $316^{\circ} \mathrm{C}$. (b) Logarithmic plot of descaled weight loss measurements shown in (a). In order to eliminate surface effects, the data have been normalized to exclude weight loss measurements from the first sampling interval. 
Figure $9 \mathrm{~b}$ is a logarithmic plot of the weight loss data shown in Figure 9a. Similar to the behavior of the 304SS, all of the carbon steel coupons exhibited a relatively large weight loss in the first sampling interval, ranging between 0.2 and $0.5 \mathrm{mg} / \mathrm{cm}^{2}$. As before, it is necessary to normalize the data to remove the short-term effects in order to identify the corrosion kinetics. Here too, the small weight change measurements coupled with the scatter in the data preclude unambiguous interpretation of Figure $9 \mathrm{~b}$. However, the coupons exposed to mixtures \#1-3 tend to exhibit nearly linear weight loss kinetics. For the remaining binary mixtures (\#4-7), the kinetics appear to more closely follow parabolic or one-half power kinetics, suggesting an oxidation process that yields more protective scales than for the first three mixtures. Other studies have shown that carbon steels can display parabolic oxidation kinetics in molten nitrates during short (10 hours) immersion times [810].

\section{Oxide Adherence}

In contrast to the stainless steel coupons, the carbon steel coupons did not show any spallation of oxides to the bare metal upon visual examination. To estimate the amount of spallation, the same protocol used above was applied to the weight change data obtained for carbon steels. The results of these calculations are presented in Table IX and generally show that oxides on the carbon steel specimens immersed in mixtures \#4-\#7 are adherent even after 7000 hours of immersion. This adherence is no doubt partly due to the relatively thin layers that grow at the lower temperature of these tests. Thinner layers generate both lower growth stresses as well as lower thermally-induced stress upon cooling. The calculated adherence factors for the specimens immersed in mixtures \#1-\#3 are somewhat less than unity and the weight loss data presented in Figure $9 \mathrm{~b}$ indicate that the corrosion kinetics are more accurately described as linear.

The rather low amounts of corrosion rendered microscopy ineffective as an analytical tool for characterizing the structure and composition of the residual corrosion products simply because the oxide scales were only 2 to $4 \mu \mathrm{m}$ in thickness, based on weight change data. However, X-ray diffraction showed the scale to consist of two phases, a dominant $\mathrm{Fe}_{3} \mathrm{O}_{4}$ spinel phase and a minor phase corresponding to $\mathrm{Fe}_{2} \mathrm{O}_{3}$.

We have not discussed the structure and composition of the oxide layers formed on the alloys immersed in the ternary mixture. This is due principally to the minimal corrosion experienced by all the stainless steels at the low exposure temperature. The very thin surface scales formed on the stainless coupons precluded any quantitative or even qualitative analysis of the type discussed above. We note however, that the A 36 coupons exposed to the ternary mixture (\#T) exhibited lower weight losses than those in any of the binary mixtures at the same temperature. It was evident that a different type of oxide was formed on carbon steel in the ternary salt since it was difficult to descale these coupons compared to the others.

\section{Salt Composition}

The concentrations of the impurity species were analyzed periodically to monitor the compositional changes of the nitrate mixtures as well as to detect the presence of dissolved corrosion products. As expected, the major change in composition occurred due to the dissociation reaction of nitrate which forms nitrite and oxygen. Figure 10a shows the nitrite concentration in each mixture at $570^{\circ} \mathrm{C}$ throughout the course of the experiments. From an initial value of essentially zero for all mixtures, the nitrite concentration increased to $3.5 \%$ to $5.5 \%$. These values agree quite well with the calculated value of $3.6 \mathrm{wt}$. \% based on 
equilibrium between nitrate, nitrite and air at $570^{\circ} \mathrm{C} \mathrm{[18].} \mathrm{The} \mathrm{concentration} \mathrm{of} \mathrm{nitrite} \mathrm{was}$ negligible in the low temperature crucibles as expected.

The chloride concentrations in a number of mixtures increased slightly during the first 1608 hours of the test. The increases in chloride occurred in concert with a corresponding and stoichiometric decrease in perchlorate $\left(\mathrm{ClO}_{4}{ }^{-}\right)$concentration until, at 1608 hours, the perchlorate concentration in all of the high temperature crucibles was essentially zero. The chloride levels then stabilized at the higher values. Although perchlorate ion is reported to be stable in $\mathrm{KNO}_{3}$ at $450^{\circ} \mathrm{C}$ [19], it can be reduced to chloride by a number of reactions. A redox reaction would likely occur with nitrite since a stoichiometric excess of nitrite is present. The free energy change for perchlorate reduction by nitrite is favorable based on the data available for low temperature [20]. Perchlorate can also be reduced by metallic corrosion or by other impurities in the melts. The rate of perchlorate reduction was much slower in the low temperature mixtures.

The sulfate concentrations of the various high temperature mixtures were essentially stable during the tests. However, it is notable that the two mixtures that have appreciable sulfate concentrations (\#4 and \#5, see Table 2) yielded stainless steel coupons that had surface scales with a distinctive rust-red coloration indicative of hematite $\left(\mathrm{Fe}_{2} \mathrm{O}_{3}\right)$. In all of the other mixtures the sulfate concentration was negligible and the residual surface scales were dark gray or black, typical of magnetite $\left(\mathrm{Fe}_{3} \mathrm{O}_{4}\right)$. The implication is that the thermodynamic activity of oxygen in mixtures containing sulfate was somewhat higher than the other mixtures, although it is unclear how sulfate could cause this. At $316^{\circ} \mathrm{C}$, no hematite was observed on carbon steel in either mixture \#4 or \#5.

The concentration of carbonate (see Figure 10b) increased steadily in the high temperature tests due to the absorption of carbon dioxide from the air bubbled through the melts (Note: a straightforward calculation indicated that the amount of carbon available from the alloys was insufficient to account for any appreciable concentration of carbonate). Carbon dioxide is a Lux-Flood acid and may be absorbed directly by these basic melts, or it may form carbonate by reducing nitrate [21]. The alkalinity of the melts was entirely due to the accumulation of carbonate; no free oxide was detected. Although dissolved carbonate has been reported to increase the corrosion rates of stainless steels in molten nitrates based on weight gain measurements [15], our weight loss data do not support this claim. For example, Fig. 10b shows that mixture \#4 had the highest concentration of carbonate over the course of the experiments, but this mixture was no more corrosive than others that contain comparable amounts of impurities, e.g., \#5, \#6 or \#7, as evident from Tables IV or $\mathrm{V}$.

Salt samples from each high temperature crucible were analyzed for dissolved chromium $(\mathrm{Cr})$ and manganese $(\mathrm{Mn})$ since the oxidation products of these alloying elements (chromates and manganates) are soluble in molten nitrates [2]. Figure 10c shows the increase in chromium concentration. After the initial rapid increase between 0 and 864 hours, the chromium concentration remained nearly constant. In fact, it appears to have decreased somewhat, suggesting that the solubility limit of an unidentified metallic chromate compound was reached. The manganese concentration continued to increase with time although at a much lower level than chromium due to its relatively low concentration in the alloys. Analyses for iron and nickel were not performed since these elements do not form soluble species in the nitrate salts [2].

The observations above demonstrate that changes in the composition of these salt mixtures were generally consistent with the thermodynamic processes of the binary nitrate system and with the corrosion processes observed. 


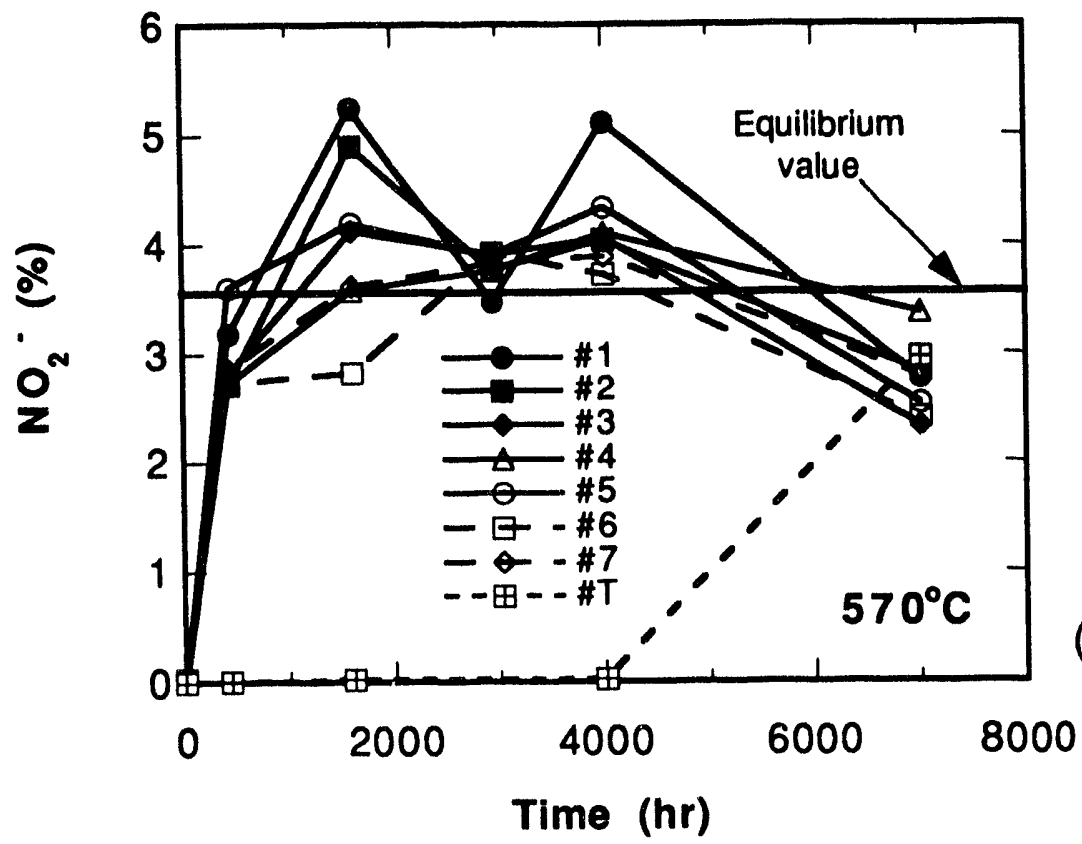

(a)

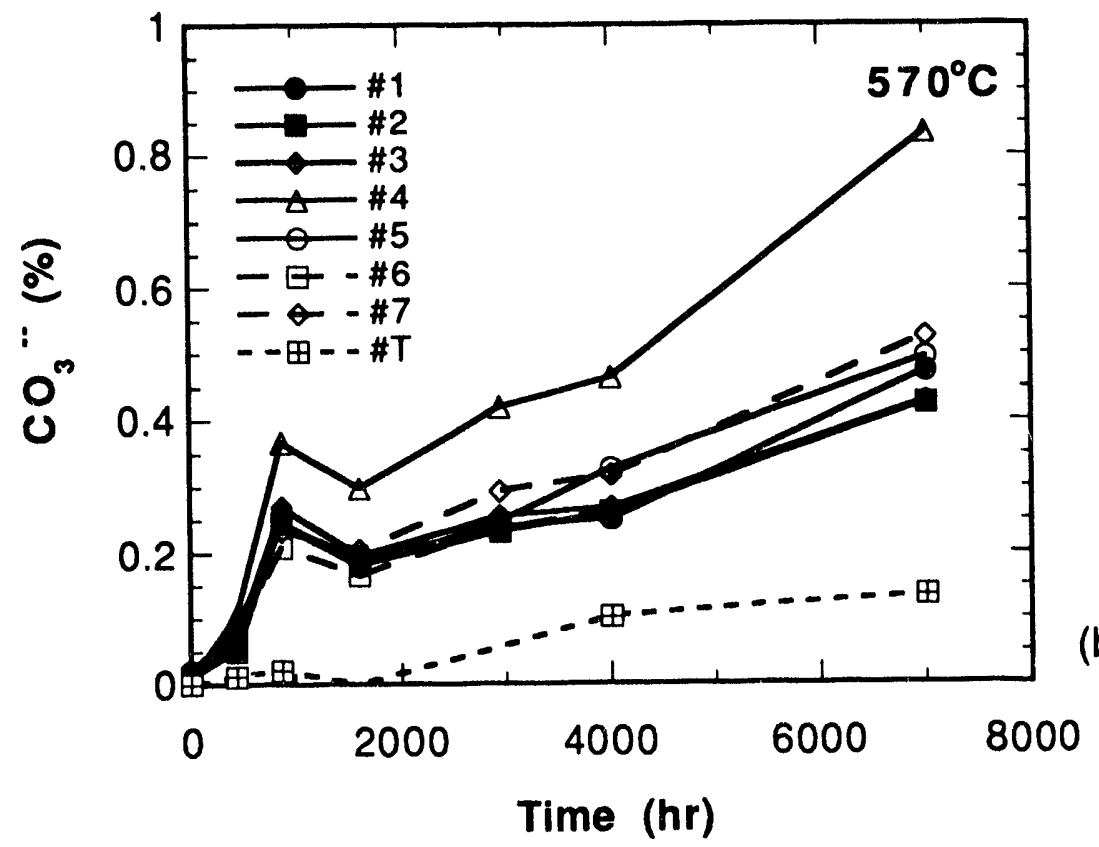

(b)

Figure 10. Chemical analysis of selected constituents in the molten nitrate salt mixtures during the corrosion tests at $570^{\circ} \mathrm{C}$. a) concentration of nitrite $\left(\mathrm{NO}_{2}^{-}\right)$ b) concentration of carbonate $\left(\mathrm{CO}_{3}^{--}\right)$ 


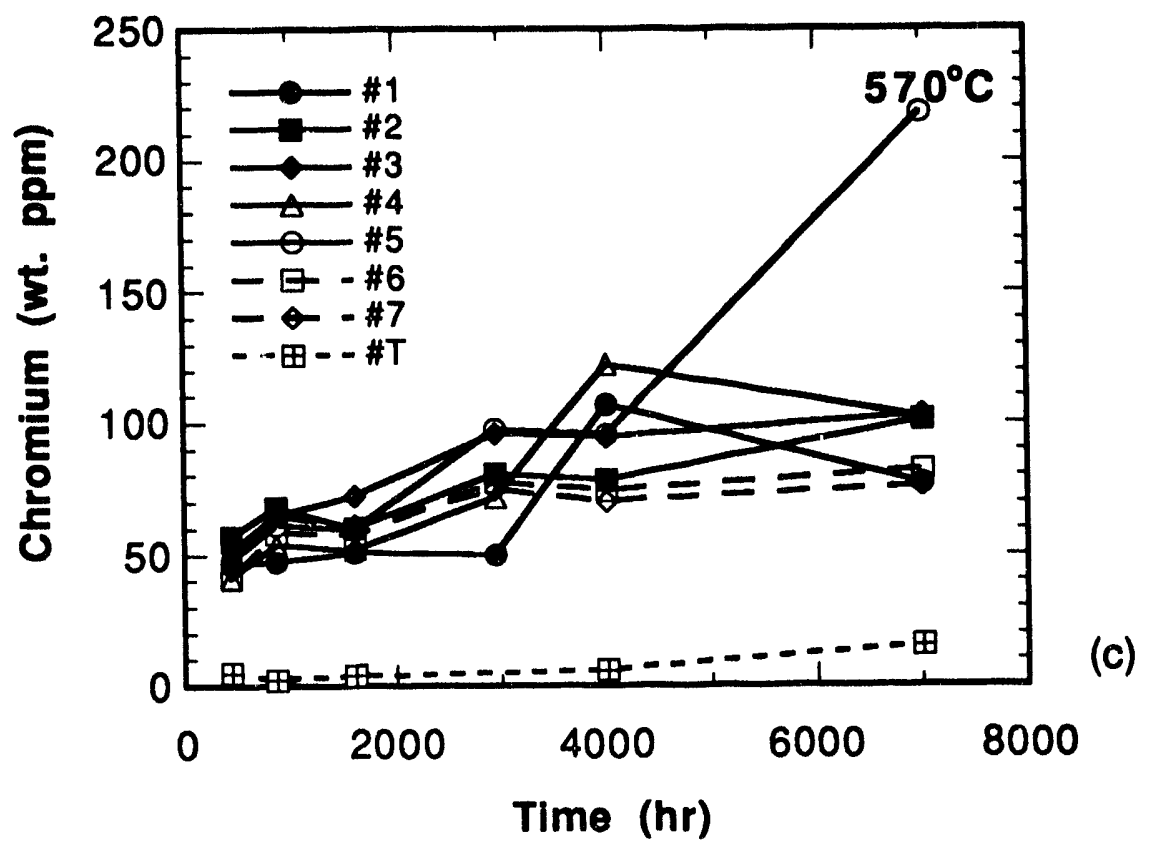

Figure $10(\mathrm{c})$. Concentration of dissolved chromium in the molten nitrate salt mixtures during the corrosion tests at $570^{\circ} \mathrm{C}$. 


\section{SUMMARY}

The experimental data presented here show that the impurities typically contained in commercial grades of alkali nitrates have relatively small effects on corrosion of stainless and carbon steels in molten salts prepared from these constituents. The corrosion rates of 316SS and 304SS imply that metal losses of 6 to $15 \mu \mathrm{m} / \mathrm{year}$ may be anticipated during isothermal service at $570^{\circ} \mathrm{C}$. For the $304 S S$ coupons, the influence of increasing chloride concentration was evident, viz., the rate of weight loss increased as the chloride concentration increased. However, the magnitude of the effect was not significant in the context of the engineering application. No single rate law could be ascribed to the corrosion kinetics for the alloy in all of the mixtures. The low chloride mixtures tended to exhibit parabolic kinetics while the remainder of the mixtures exhibited approximately linear kinetics. For 316SS, weight loss generally followed parabolic corrosion kinetics at short times, transitioning to linear kinetics at longer exposure times. Corrosion rates for 316 SS were largely insensitive to the impurity content of the melts. Elemental analysis of the corrosion products on the stainless steel coupons revealed that they consisted of a complex mixture of iron-based oxides that contained several other elements derived from both the alloying elements (chromium, manganese) and constituents of the molten salt (sodium, magnesium).

The differences between the corrosion behavior of the two types of stainless steel tested may well arise from differences in the initial surface finish of the test coupons or from minor differences in their elemental compositions.

Neither the incomplete oxide adherence of the stainless steel samples nor the gradual evolution of porosity in the alloys immediately below the surface scale have been previously observed. These particular results indicate the need to conduct corrosion tests using non-isothermal conditions to obtain reliable estimates of corrosion allowances for components such as receiver tubes that necessarily undergo daily thermal cycling between the maximum and ambient temperatures. These tests are in progress at the time that this report was printed.

The experimental data demonstrate that at $316^{\circ} \mathrm{C}, \mathrm{A} 36$ carbon steel is relatively tolerant to the impurities typically found in commodity grades of alkali nitrates. The influence of deliberate additions of chloride to a high-purity nitrate mixture was not clearly evident. While there appears to be some difference in the corrosion behavior among various salt mixtures, the overall weight losses were modest and correspond to corrosion rates of about $5 \mu \mathrm{m} / \mathrm{yr}$. Oxide layers, which consisted primarily of magnetite, were generally adherent during these long-term tests.

The chemical changes that occurred in the molten salts throughout the tests were generally those expected from the known thermodynamic properties of the constituents and no degradation of the salts was observed. 


\section{REFERENCES}

1. W. von Keinschmidt and P. DeLaquil, Solar Two Central Receiver Project, Sixth Intl. Symposium on Solar Thermal Concentrating Technologies, Mojacar, Spain, Sept. 28 - Oct. 2, 1992.

2. R. W. Bradshaw and R. W. Carling, A Review of the Chemical and Physical Properties of Molten Alkali Nitrate Salts and Their Effect on Materials Used for Solar Central Receivers, Sandia National Laboratories, SAND87-8005, April 1987.

3. R. W. Bradshaw, Corrosion of $304 \mathrm{SS}$ by Molten $\mathrm{NaNO}_{3}-\mathrm{KNO}_{3}$ in a Thermal Convection Loop, Sandia National Laboratories, SAND80-8856, Dec. 1980.

4. $\quad$ S. H. Goods, J. Matl. Energy Sys., 5:28 (1983).

5. S. H. Goods, Mechanical Properties of Alloy Steels in Molten Sodium-Potassium Nitrate Salts, High Temperature Corrosion in Energy Systems, M. F. Rothman, Ed. (The Metallurgical Society of AIME, 1985).

6. P. Hancock, Oxid. Metals, 23:305 (1985).

7. I. B. Singh and U. Sen, Brit. Corros. J., 27:299 (1992).

8. A. A. El Hosary, A. Baraka, and A. I. Abdel-Rohman, Brit. Corros. J., 11:228 (1976).

9. A. Baraka, A. I. Abdel-Rohman, and A. A. El Hosary, Brit. Corros. J., 11:44 (1976).

10. T. Notoya, T. Ishikawa, and R. Midorikawa, Proc. Fifth Int'l. Congress on Metallic Corrosion (N.A.C.E., 1972), p. 1039.

11. I. Kayafas, Corrosion, 36:443 (1980).

12. N.A.C.E. Technical Practices Committee, Materials Performance, 6:69 (1967).

13. R. W. Bradshaw, S. H. Goods, M. R. Prairie, and D. R. Boehme, Corrosion of Carbon Steel and Stainless Steels In Molten Nitrate Mixtures, Proceedings of the International Symposium on Molten Salt Chemistry and Technology - 1993, PV-93-9 (The Electrochemical Society, May 1993), p. 446.

14. J. Armitt, et al, The Spalling of Steam Grown Oxide from Superheater and Reheater Tube Steels, Central Electricity Generating Board (U.K.), RD/L/R 1974 (Feb. 1978).

15. Martin-Marietta Corp., Alternate Central Receiver Power System, Phase II, Final Report, Vol. III-Molten Salt Materials Tests, SAND81-8192/3 (Jan. 1984).

16. Chemical composition specification sheets, Chilean Nitrate Corporation, Norfolk, VA.

17. D. R. Boehme and R. W. Bradshaw, High Temp. Sci., 18:39 (1984).

18. L. A. Nissen and D. E. Meeker, Inorg. Chem., 22:716 (1981).

19. O. J. Kleppa and S. V. Meschel, J. Phys. Chem., 67:2750 (1963).

20. I. Barin, O. Knacke, and O. Kubachewski, Thermochemical Properties of Inorganic Substances, (Springer-Verlag, 1977).

21. S. H. White and U. M. Twardoch, A Study of the Interactions of Molten Sodium Nitrate-Potasssium Nitrate 50 mol\% Mixture with Water Vapor and Carbon Dioxide in the Air, EIC Laboratories (Sept. 1981). 
UNLIMITED RELEASE

INITIAL DISTRIBUTION

U.S. Department of Energy (3)

Forrestal Building

Code EE-132

1000 Independence Avenue, SW

Washington, DC 20585

Attn: Gary D. Burch

$N$. Haque

S. Gronich

U.S. Department of Energy (2)

Golden Field Office

1617 Cole Boulevard

Golden, CO 80401

Attn: Bob Martin

Project Manager

Advanced Thermal Systems

7600 East Arapahoe

Suite 319

Englewood, CO 80112

Attn: D. Gorman

Arizona Public Service Company

P. O. Box 53999, MS 1424

Phoenix, AZ 85072-3999

Attn: Scott McLellan

Joe McGirk

Babcock and Wilcox

91 Stirling Avenue

Barberton, OH 44203

Attn: P. A. Bator

Battelle Pacific Northwest

Laboratory

P.O. Box 999

Richland, WA 99352

Attn:

D. Brown

Bechtel National, Inc. (3)

50 Beale Street

4S/26/

P. O. Box 193965

San Francisco, CA 94119-3965

Attn:

P. DeLaquil

B. Kelly

A. Zavoico

Bureau of Reclamation

Code D-3710

P. O. Box 205007

Denver, CO 80225

Attn: Stanley Hightower
California Energy Commission

1516 Ninth Street, M-S 43

Sacramento, CA 95814

Attn: A. Jenkins

Centro Investigations Energetica

Medroansental Technologie (CIEMAT)

Avda. Complutense, 22

28040 Madrid, SPAIN

Attn: M. Macias

DFVLR, HA-ET

Linder Hoehe

P. O. Box 906058

5000 Cologne 90, GERMANY

Attn: M. Becker

M. Boehmer

Electric Power Research Institute (2)

3412 Hillview Avenue

P.O. Box 10412

Palo Alto, CA 94303

Attn: E. DeMeo

D. Morris

Foster Wheeler Solar Development

Corporation

12 Peach Tree Hill Road

Livingston, NJ 07039

Attn: S. F. Wu

Dick Holl, President

Jenna Baskets

2475 Coral Street, Suite D

Vista, CA 92083

Idaho Power

P. O. Box 70

Boise, ID 83707

Attn: Jerry Young

Kearney \& Associates

14022 Condessa Drive

Del Mar, CA 92014

Attn: David W. Kearney

Los Angeles Department of Water and Power

Alternate Energy Systems

Room 661A

111 North Hope Street

Los Angeles, CA 90012

Attn: Darryl Yonamine

National Renewable Energy Lab (2)

1617 Cole Boulevard

Golden, CO 80401

Attn: Tom Williams

Mark Bohn 
Pasadena Water and Power Division 150 South Los Robles Avenue

Suite 200

Pasadena, CA 91101

Attn: Manny Robledo

Platforma Solar de Almeria (2)

Aptdo. 7

Tabernas (Almeria)

E-04200 SPAIN

Attn: M. Sanchez

W. Grasse

Rockwell International

Rocketdyne Division

6633 Canoga Avenue

Canoga Park, CA 91303

Attn: $\quad$ M. Marko, MS FA70

E. Baughmesiter

Sacramento Municipal Utilities District

P. O. Box 15830

Sacramento, CA 95852-1830

Attn: Robert Wichert Larry Wittrup

Salt River Project

Research and Development

P. O. Box 52025

Phoenix, AZ 85072-2025

Attn: Bob Hess

Ernie Palamino

Science Applications International Corporation

2109 Airpark Road, SE

Albuquerque, NM 87106

Attn: D. Smith

Science Applications International Corporation

15000 W. 6th Avenue, Suite 202

Golden, CO 80401

Attn: Kelly Beninga

Solar Power Engineering Company

P.O. Box 91

Morrison, CO 80465

Attn: H. C. Wroton

Southern California Edison

2244 Walnut Grove Avenue

P. O. Box 800

Rosemead, CA 91770

Attn:

C. Lopez

D. Brundage

M. Skowronski
Tom Tracey

6922 South Adams Way

Littleton, CO 80122

University of Houston

Solar Energy Laboratory

4800 Calhoun

Houston, TX 77704

Attn: L. Vant-Hull

University of Nevada at Las Vegas

Howard R. Hughes Coll of Engineering

4505 Maryland Parkway

Las Vegas, NV 89154-4026

Attn: Robert F. Boehm

Utah Power

1407 West North Temple

Salt Lake City, UT 84140-0001

Attn: Ian Andrews

MS 0129 J. A. Leonard, 12611

MS 0129 Lori Parrott, 12610

MS 9014 S. Faas, 5371

MS 1393 A. Baker, 5609

MS 0735 D. E. Arvizu, 6200

MS 0735 D. J. Alpert, 6200

MS 0704 P. C. Klimas, 6201

MS 0753 G. J. Jones, 6202

MS 0702 N. J. Magnani, 6204

MS 0710 A. P. Sylwester, 6211

MS 0709 H. P. Stephens, 6212

MS 0752 T. C. Bickel, 6213

MS 0708 H. M. Dodd, 6214

MS 1127 C. P. Cameron, 6215

MS 1127 M. E. Ralph, 62.15

MS 1127 E. E. Rush, 6215

M's 1127 J. W. Strackan, 6215

MS 0703 C. E. Tyner, 6216

MS 0703 J. M. Chavez (5), 6216

MS 0703 M.R. Prairie (5), 6216

MS 0703 G. J. Kolb, 6216

MS 0703 T. R. Mancini, 6216

MS 0703 D. F. Menicucci, 6216

MS 0703 J. E. Pacheco, 6216

MS 0703 H. E. Reilly, 6216

MS 0753 D. E. Hasti, 6218

MS 0752 M. L. Whipple, 6219

MS 0320 P. L. Mattern, 1010

MS 0336 R. J. Eagan, 1700

MS 0337 A. D. Romig, 1800

MS 0340 R. J. Salzbrenner, 1832

MS 0341 J. A. Van Den Avyle, 1833

MS 0469 J. W. Hickman, 5001

MS 0755 V. M. Loyola, 6612 
MS 0871 H. Hanser, 5409

MS 9001 J. C. Crawford, 8000

Attn: D. L. Crawford, 1900

E. E. Ives, 5200

J. B. Wright, 5300

M. E. John, 8100

R. J. Detry, 8200

W. J. McLean, 8300

L. A. Hiles, 8400

P. N. Smith, 8500

L. A. West, 8600

M. T. Dyer, 8800

MS 9042

G. A. Benedetti, 8741

MS 9042

P. E. Nielan, 8742

MS 9043

D. J. Bammann, 8743

MS 9043

MS 9044

M. L. Callabresi, 8743

MS 9401

MS 9401

W. A. Kawahara, 8746

C. W. Robinson, 8702 ,

R. C. Wayne, 8700

Attn: W. D. Wilson, 8703

J. E. Costa, 8711

G. J. Thomas, 8715

R. J. Kee, 8745

MS 9402 S. H. Goods (5), 8714

MS 9402 M. W. Perra, 8714

MS 9403 M. I. Baskes, 8712

MS 9404 J. C. F. Wang, 8713

MS 9404 R. W. Bradshaw (5), 8716

MS 9404 J. M. Hruby, 8716

MS 9021 Technical Communications for OSTI (10)

MS 9021 Technical Conimunications/Technical Library Processes, 7141

MS 0899 Technical Library Processes Dept., 7141 (4)

MS 9018 Central Technical Files, 8523-2 (3) 


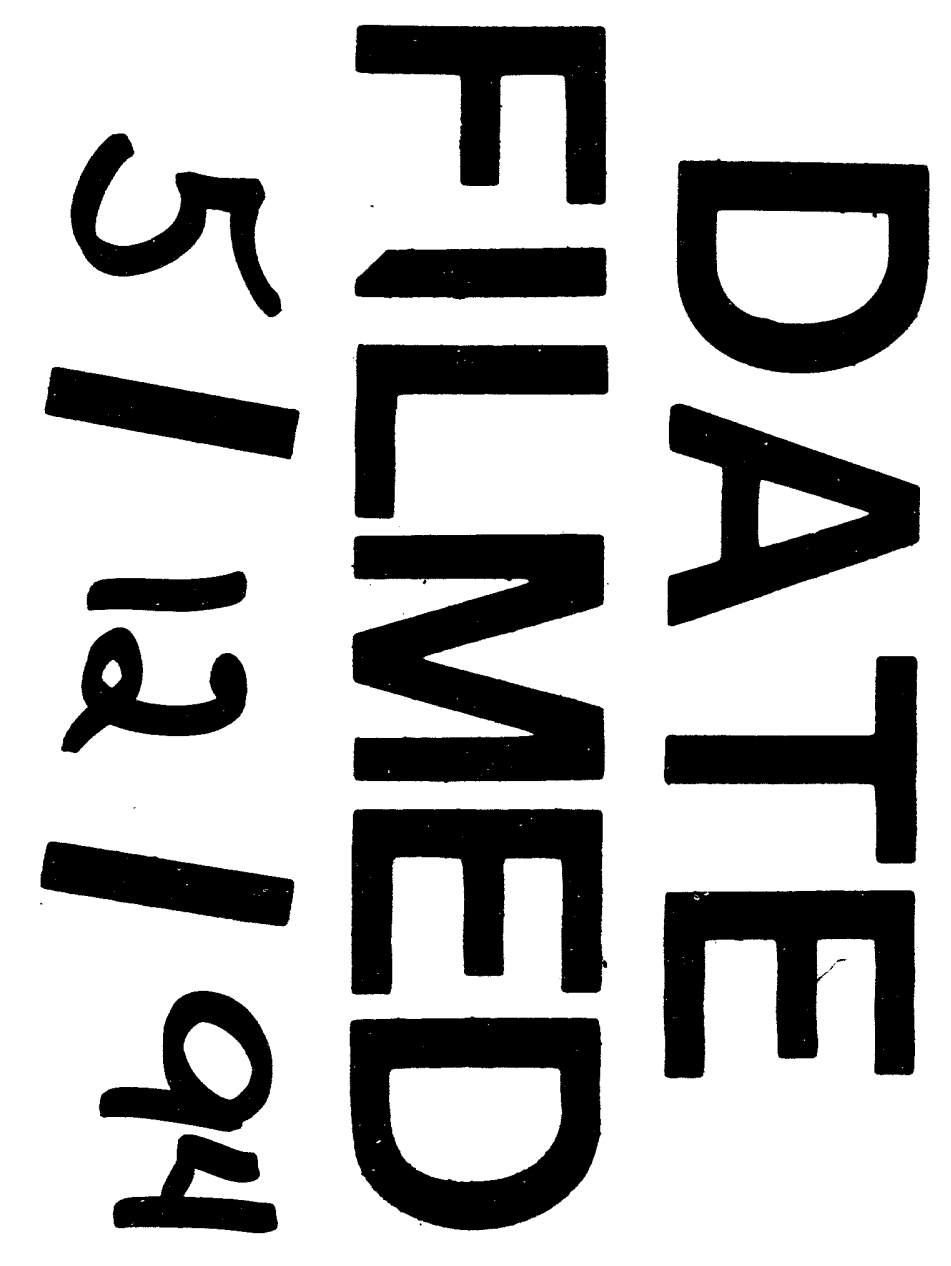


